\title{
Conodont biostratigraphy and carbonate microfacies of the Late Devonian to Mississippian Milivojevića Kamenjar section (Družetić, NW Serbia)
}

\author{
Milan N. Sudar, Matevž Novak, Dieter Korn \& Divna Jovanović
}

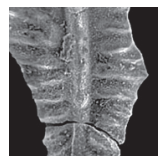

\begin{abstract}
The conodont stratigraphy, biostratigraphy and carbonate microfacies in the Milivojevića Kamenjar section (Družetić, NW Serbia) are analysed. Based on conodonts and ammonoids, the rock succession spans a period ranging from the late Famennian (Devonian) through to the Serpukhovian (late Mississippian). Nine conodont zones are recorded (one only tentatively): one Famennian zone (Lower Si. praesulcata Zone), two Tournaisian zones (Si. sulcata and Si. duplicata s. lato zones), four Viséan zones (Lo. commutata, Gn. praebilineatus, Gn. bilineatus bilineatus and Lo. nodosa zones) and two Serpukhovian zones (Lo. ziegleri and Gn. bilineatus bollandensis zones). Five carbonate microfacies are identified in the section; they indicate mostly open-marine deep shelf and deep slope settings. Conodonts and ammonoids as well as carbonate microfacies from the Milivojevića Kamenjar section reveal a Viséan-Serpukhovian transition similar to that known from the South Urals. $\bullet$ Key words: biostratigraphy, conodonts, carbonate microfacies, Viséan-Serpukhovian boundary, Famennian, Mississippian, Jadar Block.
\end{abstract}

Sudar, M.N., Novak, M., Korn, D. \& Jovanović, D. 2018. Conodont biostratigraphy and microfacies of the Late Devonian to Mississippian Milivojevića Kamenjar section (Družetić, NW Serbia). Bulletin of Geosciences 93(2), 163-183 (9 figures, 1 appendix). Czech Geological Survey, Prague. ISSN 1214-1119. Manuscript received August 19, 2017; accepted in revised form January 18, 2018; published online June 18, 2018; issued June 30, 2018 .

Milan N. Sudar, Serbian Academy of Sciences and Arts, Knez Mihailova 35, 11000 Belgrade, Serbia; milan.sudar1946 @gmail.com • Matevž Novak, Geological Survey of Slovenia, Dimičeva ul. 14, SI-1000 Ljubljana, Slovenia; matevz.novak@geo-zs.si •Dieter Korn, Museum für Naturkunde, Leibnitz Institute for Evolution and Biodiversity Science, Invalidenstraße 43, 10115 Berlin, Germany; dieter.korn@mfn-berlin.de•Divna Jovanović, Geological Survey of Serbia, Rovinjska 12, 11000 Belgrade, Serbia; djdivna@gmail.com

Mississippian fossiliferous sections are very rare in the Balkan Peninsula and little is known about the palaeogeographic relationships between this region and other areas (e.g. South Urals, Central Europe, Southern Europe, Iberian Peninsula, British Islands, North Africa) with well-established zonations based on conodonts (e.g. Sandberg et al. 1978; Corradini 2003, 2008; Kaiser et al. 2009; Corradini et al. 2016, etc.) and ammonoids (e.g. Korn 1996, Korn et al. 2007). The diverse fossil content of the limestone olistolith in the Milivojevića Kamenjar outcrop makes this the best key site for Carboniferous stratigraphy and palaeogeography in the Balkan Peninsula. The fossil site was discovered sixty years ago; the first description of rather diverse ammonoid assemblages from this locality was published by Stevanović \& Kullmann (1962). In this monographic article, two fossil horizons were distinguished with a total of twelve ammonoid species. Already in this first description, controversial opinions on the geological setting were expressed (for a review, see Korn et al. 2010a). Ruzhencev \& Bogoslovskaya (1971) did already comment on some mistakes in the original taxonomic determinations (of some ammonoid species and genera) and the stratigraphic conclusions drawn from the ammonoid assemblages. Therefore, it became evident that a revision of the stratigraphy (ammonoids and conodonts) and of the whole sedimentary succession is necessary. Following the studies on the ammonoids by Stevanovic \& Kullmann (1962), investigation of conodonts (Spasov \& Filipović 1967, Scharfe 1977, Stojanović-Kuzenko \& Pajić in Filipović 1995) and other faunal elements (Filipović 1995) suggested the potential of this section for stratigraphic correlation with other regions.

We undertook a new investigation of the Milivojevića Kamenjar outcrop since 2008 by sampling the entire section in terms of ammonoids, conodonts and carbonate microfacies. In this process, we already published a series of papers dealing with the revision of the ammonoids, including a discussion of the stratigraphic age and the palaeogeographic position between Laurussia and Gondwana (Korn \& Sudar 2010, 2016; Korn et al. 2010a, b, c, d, 2012). 

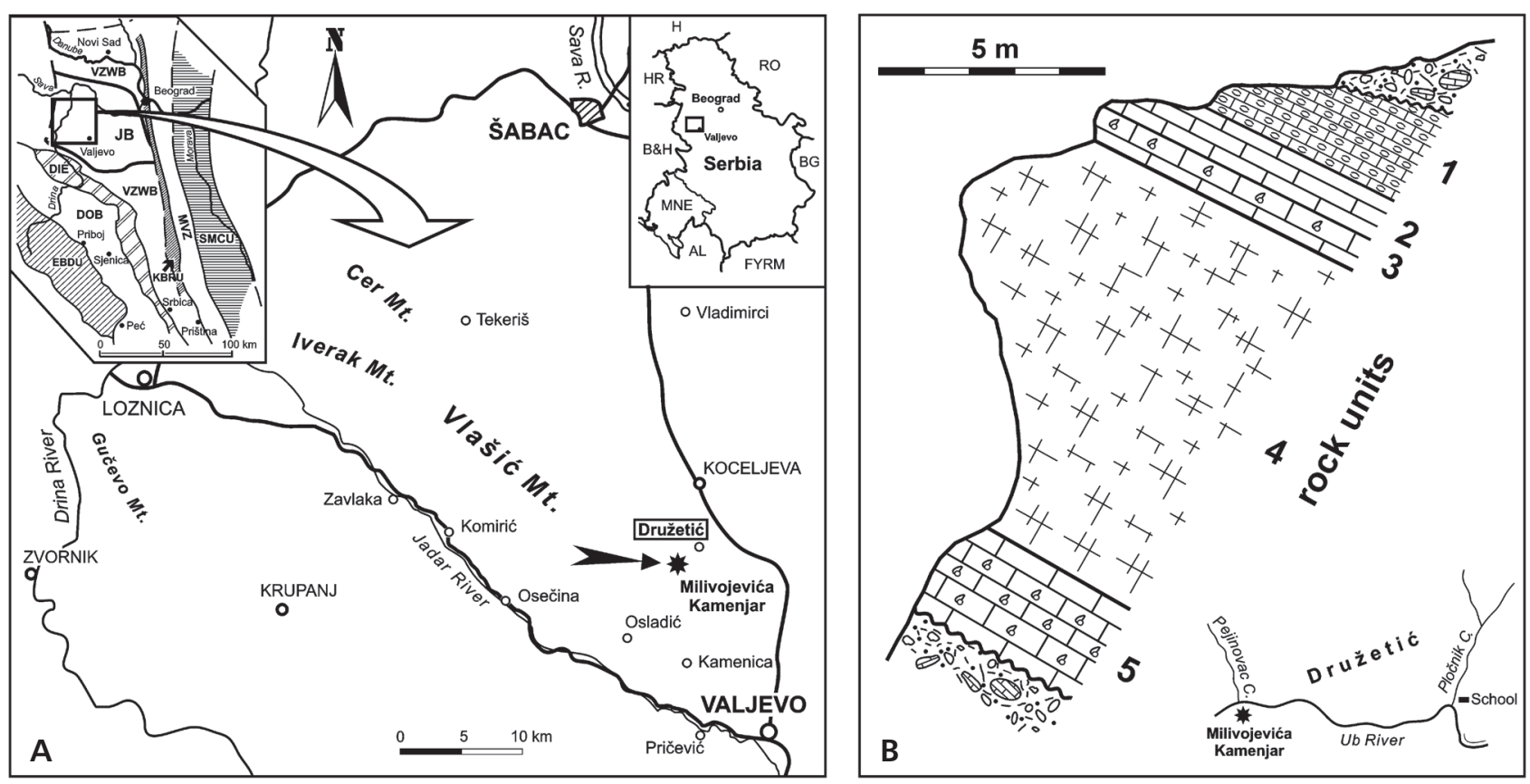

Figure 1. A-geographic and geological location of the Milivojevića Kamenjar section in the Jadar Block (Družetić, NW Serbia). Tectonostratigraphic units of part of the Balkan Peninsula: SMCU - Serbian-Macedonian Composite Unit; MVZ - Main Vardar Zone; KBRU - Kopaonik Block and Ridge Unit; VZWB - Vardar Zone Western Belt; JB - Jadar Block; DIE - Drina-Ivanjica Element; DOB - Dinaridic Ophiolite Belt; EBDU - East BosnianDurmitor Unit. $\bullet$ B - field position of the overturned carbonate block/olistolith in the Milivojevića Kamenjar section; the succession is subdivided into five rock units in descending order (i.e. from oldest at the top of the section to youngest at the base) (simplified from Korn \& Sudar 2016).

The main objectives of our study are: (1) the detailed investigation of the Viséan-Serpukhovian transitional beds to provide new information to help in the search of a GSSP for this stage boundary. (2) The study of the conodont succession and the carbonate microfacies of the Milivojevića Kamenjar section.

\section{Geographic and geological setting of the Milivojevića Kamenjar section}

Since the geographic and geological setting of the studied section has been described several times in detail by Korn $e t$ al. (2010a, b, c), here we will only briefly review the main geological features of the outcrop. The Milivojevića Kamenjar section $\left(44.41914^{\circ} \mathrm{N}, 19.81285^{\circ} \mathrm{E}\right)$ is geographically located in an old abandoned quarry in the south-western area of the Družetić Village, on the right side of the Ub river, $24 \mathrm{~km}$ north of Valjevo on the north-eastern slopes of the Vlašic Mountain in north-western Serbia. Structurally, it belongs to the Jadar Block that is located at the southern margin of the Pannonian Basin, which is a part of the Vardar Zone. In the
Serbian geological literature, the Jadar Block is considered to be an isolated exotic block, in which Dinaridic features dominate (Filipović et al. 2003, Karamata 2006) (Fig. 1).

In the wider area of Družetić, the older olistostromal part of the Ivovik Formation belonging to the Ub Unit within the Jadar Autochthon is composed of a siltstone matrix with clasts and olistoliths of Devonian and Mississippian limestone of the Družetić Formation (Filipović et al. 2003, Korn et al. 2010a). The Milivojevića Kamenjar section crops out in an overturned olistolith, in which the stratigraphic succession is inverted. In this reworked block, which is almost exclusively composed of carbonates, the bedding planes are inclined with $10^{\circ}$ to $25^{\circ}$ in south-western direction.

\section{The rock succession and ammonoid biostratigraphy}

In our previous papers (e.g. Korn et al. 2010a), we outlined the approximately 15 metres thick rock succession in the overturned olistolith, but new trenching shows that the total thickness is nearly 17 metres. The succession can be

Figure 2. Geological column with vertical distribution of determinated conodont species, conodont zones and carbonate microfacies of the carbonate block/olistolith in the Milivojevića Kamenjar section in the Jadar Block (Družetić, NW Serbia) with the Late Devonian and Mississippian stratigraphic succession illustrated in correct stratigraphic order. Note: Tourn. = Tournaisian; bispath. = bispathodus. 


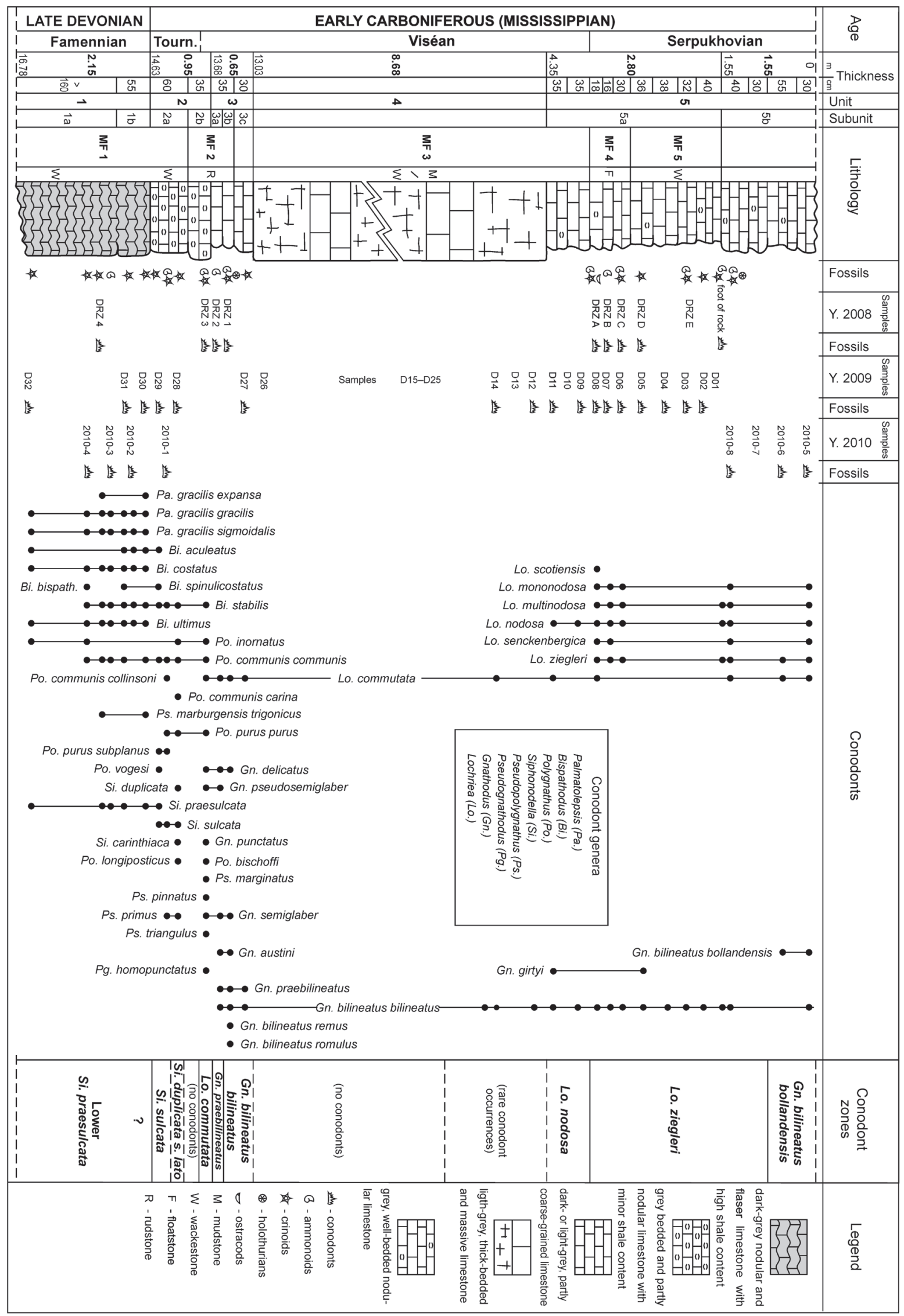


subdivided into five rock units in descending order (i.e. from oldest at the top of the outcrop to youngest at the base, Fig. 1B); illustrated in Fig. 2 in correct stratigraphic order. After the publication of first data (Stevanović \& Kullmann 1962) with the distinction of two ammonoid horizons, Korn et al. (2010a, b, c) re-described the rock column in greater detail. Korn et al. (2010a) and Korn \& Sudar (2016) presented the ammonoid stratigraphy for the outcrop; they separated five ammonoid assemblages corresponding to the five rock units (Fig. 3):

Unit 1 (with two subunits); 2.15 m thick. - Dark-grey, nodular or flaser limestone with high shale content. It is strongly affected by diagenetic compaction as well as lateral and vertical tectonic deformation. Macrofossils are poorly preserved and involve fragmentary ammonoids of latest Famennian age. The composition of ammonoid assemblage 1 (Fig. 3) with several clymeniids can be assigned to the early "Wocklumeria Stufe" in the traditional terminology (Korn \& Sudar 2016). This record represents the first known occurrence of clymeniids record from the Balkan Peninsula (Korn et al. 2010b, Korn \& Sudar 2016).

Unit 2 (with two subunits); $0.95 \mathrm{~m}$. - Grey bedded and partly nodular limestone with minor shale content. Few ammonoids of unspecified ("middle") Tournaisian age were collected from a single horizon at the top of the unit (ammonoid assemblage 2 in Fig. 3).

Unit 3 (with three subunits); $0.65 \mathrm{~m}$. - Dark-grey or lightgrey, bedded limestone, partly coarse-grained with high dolomite content. This unit is very rich in fossils, particularly in ammonoids, which were collected from two subunits ( $3 \mathrm{a}$ and $3 \mathrm{~b}$, together $35 \mathrm{~cm}$ thick). The two horizons in ammonoid assemblage 3 (Fig. 3) differ only slightly in the species compositions and both can clearly be attributed to the Entogonites Genus Zone and are early late Viséan in age; in genus composition it is very similar to time-equivalent occurrences in Central Europe and other regions (Korn et al. 2012). The third subunit (3c, $30 \mathrm{~cm}$ thick) did not yield macrofossils. Unit 3 corresponds to the "upper fossiliferous layer" of Stevanović \& Kullmann (1962), who erroneously proposed a Namurian age.

Unit 4; 8.68m. - Light-grey, thick-bedded or massive, mostly non-fossiliferous micritic limestone.

Unit 5 (with two subunits); the entire currently exposed thickness is $4.35 \mathrm{~m}$. - Grey, well-bedded and slightly nodular micritic limestone with minor shale content and numerous limonite veins. From this unit, a number of ammonoid samples were obtained both in situ and in loose blocks. It is apparent that two complexes are represented (Fig. 2).
The older subunit (5a, $2.80 \mathrm{~m}$ thick) is characterized by lightgrey, partly sparitic limestone with numerous limonite and siderite veins. The ammonoid assemblage is latest Viséan to early Serpukhovian in age (ammonoid assemblage 5a; Fig. 3). It belongs to the Hypergoniatites-Ferganoceras Genus Zone of the South Urals. The younger complex (5b, $1.55 \mathrm{~m}$ thick) is composed of dark-grey, dense limestone without limonite veins, late Serpukhovian in age (ammonoid assemblage 5b; Fig. 3), within the Fayettevilea-Delepinoceras Genus Zone of South Urals. Ammonoid assemblages 5a and 5b are the sources of the ammonoid findings which, according to Stevanović \& Kullmann (1962), belong to the Namurian ("lower fossiliferous layer").

\section{Material and methods}

We investigated the entire Milivojevića Kamenjar section in several short field seasons between 2008 and 2012. In the first three years a detailed study of this section involving re-measuring, re-sampling and collecting the fossil content (primarily ammonoids) was performed. From each level, samples for conodonts and additional oriented samples perpendicular to bedding for petrographic and microfacies analysis were taken. In 2011 and 2012 the research was dedicated towards collecting more ammonoid specimens from the only two known ammonoid bearing intervals, as well as from loose blocks of the younger horizons.

We worked on fifty samples, each about $2 \mathrm{~kg}$ in weight, for the conodont examination. The samples were processed in the Museum für Naturkunde Berlin with dissolution using $12 \%$ acetic acid and subsequent rinsing with a $63 \mu \mathrm{m}$ sieve as well as magnetic separation of the residue.

For the sedimentological research, we collected samples from each distinctive bed in each of the rock units (Fig. 2). Twenty-three standard $(48 \times 28 \mathrm{~mm})$ and five larger $(75 \times 50 \mathrm{~mm}$; from coarse-grained lithology) thin sections were produced in the laboratory of the Geological Survey of Slovenia. We retained the upright sample orientation with respect to the succession of strata in the section.

The conodonts and their biostratigraphy were investigated by M.N. Sudar; the carbonate microfacies was studied by M. Novak and D. Jovanović. D. Korn described the lithological characteristics of the section, discussed ammonoids, their stratigraphy and global correlation. Our results are based on the data from earlier published papers (Korn et al. 2010a, b, 2012; Korn \& Sudar 2016, etc.).

The conodonts are deposited in the collection of the Department of Palaeontology of Faculty of Mining and Geology (University of Belgrade) under the repository numbers 24-208 and abbreviated RGFMS. The figured conodont images presented herein were taken with a Scanning Electron Microscope at the Faculty of Mining and Geology, University of Belgrade. The photographs of 
thin sections were made at the Geological Survey of Slovenia, where the thin sections are also archived.

\section{Previous studies of conodont assemblages at Milivojevića Kamenjar}

After the first description of the Milivojevića Kamenjar section and their ammonoid assemblages by Stevanović \& Kullmann (1962), initial data on conodonts were provided by Spasov \& Filipović (1967). From five samples they determined the following conodonts and their respective zones (Spasov \& Filipović 1967, p. 55, Fig. 2): (i) samples 511 and 429 were assigned to the lower parts of the Famennian triangularis and quadrantinodosa zones; the authors most probably applied the conodont zonation proposed by Ziegler (1971); (ii) samples 491 and 453 from ammonoid-bearing limestone (upper and lower ammonoid levels) and a sample labelled as "Namurian?" (557), but with the unknown position in the column, were attributed by the authors as Namurian (with Gn. bilineatus, Gn. commutatus commutatus, Gn. commutatus homopunctatus, Gn. commutatus nodosus, Gn. girtyi, etc.).

Using this conodont data from the Milivojevića Kamenjar site, the presence of the Devonian strata that overlie those of Namurian age was documented for the first time.

Later, more detailed results of conodont studies were presented by Scharfe (1977) who recognized Famennian ("Pa. marginifera-Zone, middle Scaphiognathus veliferZone to middle Po. styriacus-Zone and middle to upper Bi. costatus-Zone"), Tournaisian ("Ps. triangulus inaequalisZone") and Viséan ("upper Scaliognathus anchoralis-Zone, anchoralis-bilineatus-Interregnum, Gn. bilineatus bilineatusZone and Paragnathodus nodosus-Zone") conodont zones. He applied the zonation schemes of Meischner (1970) and Ziegler (1971).

Subsequent biostratigraphic results from the Milivojevića Kamenjar section were gained by the investigation of conodonts by Stojanović-Kuzenko \& Pajić (in Filipović 1995). On the top of the overturned limestone olistolith, Famennian conodonts were found which indicated lower or middle parts of the Si. praesulcata Zone. Lower in the outcrop, the following Tournaisian conodont zones were recorded: Si. sulcata Zone, Si. duplicata Zone, Si. sandbergi Zone and Scg. anchoralis Zone. The largest part of the olistolith revealed conodont zones of Viséan age: Gn. texanus Zone, Gn. bilineatus Zone and Lo. nodosa Zone. The youngest, lowermost part of the outcrop yielded conodonts of the "Kladognathus-Gnathodus girtyi group Zone" that belongs in the Serpukhovian. Stojanović-Kuzenko \& Pajić (in Filipović 1995, p. 25) used the conodont zonations published by Sandberg et al. (1978), Ziegler \& Sandberg (1984), Barskov et al. (1987) and Webster \& Groessens (1990).
Mississippian conodont assemblages from other regions of former Yugoslavia are mostly represented by species of Gnathodus (Gn. bilineatus, Gn. praebilineatus, Gn. glaber, Gn, semiglaber, Gn. pseudosemiglaber, Gn. girtyi, Gn. texanus, Gn. cuneiformis, Gn. homopunctatus) and Lochriea (Lo. commutata, Lo. mononodosa, Lo. nodosa). They are known from Jezersko, central Karavanke Mts., Slovenia (Gn. bilineatus and Lo. nodosa zones, Ramovš 1990a), Pavličevo sedlo, eastern Karavanke Mts., Slovenia (Lo. nodosa Zone, Ramovš 1993), Praprotno, Slovenia (Kolar-Jurkovšek \& Jurkovšek 1994), the Ljubija region, NW Bosnia ("upper part of the Mississippian", Spasov \& Filipović 1966; and Lo. nodosa Zone, Ramovš 1990b) and western Serbia ("Late Viséan" at Skrapež locality, Spassov 1976; and "Early Namurian" at Osečina locality, Spassov 1976).

\section{Conodont biostratigraphy}

Of the 50 processed conodont samples, 33 samples were productive with a total of 631 well-preserved platform elements. Our investigation concentrated entirely on the platform elements, and hence only these will be discussed here. Eight conodont genera were determined: Palmatolepis, Bispathodus, Polygnathus, Siphonodella, Pseudopolygnathus, Pseudognathodus, Gnathodus and Lochriea with 46 precisely identified species (Fig. 2, Appendix).

All mentioned previous conodont studies, which have been done in the Milivojevića Kamenjar section, were published only in local journals (Spasov \& Filipović 1967, Scharfe 1977, Filipović 1995). Also, the used conodont zonations, particularly by Spasov \& Filipović (1967) and Scharfe (1977), are no longer used in recent conodont studies. In our investigations, we provide new data for the correlation of the section with other regions were new zonations have been worked out (e.g. Corradini 2003, 2008; Kaiser et al. 2009; Corradini et al. 2011, 2016; Kalvoda et al. 2015; Mossoni et al. 2015; Spalletta et al. 2017).

In our study, we use the conodont zonations proposed by Sandberg et al. (1978) and Corradini $(2003,2008)$ for the Devonian-Carboniferous boundary interval, mostly because of the absence of the Protognathus fauna. For the Viséan and the Serpukhovian, we apply the conodont zonal scheme based on European data of Somerville (2008) in comparison with the zonal scheme by Lane et al. (1980).

The conodont associations in the Milivojevića Kamenjar section possess a great potential for the subdivision of a carbonate succession representing a time interval spanning from the Viséan to the late Serpukhovian. However, in the Devonian-Carboniferous boundary interval, conodonts are not abundant and because of problems with the taxonomy of early siphonodellids (see Corradini et al. 2016) and the absence of the Protognathodus species, the establishment of the conodont zones was less successfully. 
Nine conodont zones (one only tentative) can be distinguished. They range from the latest Famennian (Lower Si. praesulcata Zone) through the Mississippian (Mississippian) with the Si. sulcata and Si. duplicata s. lato zones (Tournaisian), the Lo. commutata, Gn. praebilineatus, Gn. bilineatus bilineatus and Lo. nodosa zones (Viséan) and the Lo. ziegleri and Gn. bilineatus bollandensis zones (Serpukhovian).

In the stratigraphically oldest part of the section outside of the main outcrop, Stojanović-Kuzenko \& Pajić (in Filipović 1995) recognized only one Famennian conodont zone (Si. praesulcata Zone). Older conodont faunas from the triangularis and quadrantinodosa zones (Spasov \& Filipović 1967) or from the Pa. marginifera, middle $S c p$. velifer to middle Po. styriacus-zones and middle to upper Bi. costatus zones (Scharfe 1977) were not found during our investigations; we did not reach these levels because of poor outcrop conditions.

Lower Siphonodella praesulcata Zone (unit 1; samples 2008DRZ 4, 2009-D32 to 2009-D30, 2010-4 to 2010-2; thickness $2.15 \mathrm{~m}$ ). - The range of this interval of the section is based on the presence of $\mathrm{Si}$. praesulcata together with the youngest representatives of Palmatolepis and with several Bispathodus species. The occurrence of Ps. marburgensis trigonicus is also characteristic for this zone. Beside the zonal index, the assemblage comprises the following taxa: $P$ a. gracilis expansa, $P$ a . gracilis gracilis, $P$ a gracilis sigmoidalis, $B i$. aculeatus, Bi. costatus, Bi. spinulicostatus, Bi. stabilis, Bi. bispathodus, Bi. ultimus, Bi. ultimus (morphotype of Bi. ziegleri), Po. inornatus and Po. communis communis.

Species from the so-called Protognathodus fauna (Upper praesulcata Zone) are missing in latest Famennian and earliest Tournaisian assemblages of the studied section, therefore we used the conodont zonation proposed by Sandberg et al. (1978) and Corradini (2003, 2008). The Hangenberg Event was not recognized in the Milivojevića Kamenjar section (Figs 2, 3), although this has been found in most other regions worldwide (e.g. Corradini et al. 2016).

Siphonodella sulcata Zone (unit 2, older part of subunit $2 a$; samples 2009-D29 and 2010-1; thickness about $30 \mathrm{~cm}$ ). The basal Carboniferous conodont zone is documented by the occurrence of the index species Si. sulcata together with species of Polygnathus and the rare Bispathodus. The assemblage contains Bi. spinulicostatus, Bi. stabilis, Po. communis communis, Po. purus purus, Po. purus subplanus, Po. vogesi, Si. praesulcata, and Ps. primus (with some specimens of morphotype Ps. dentilineatus).

Siphonodella duplicata Zone s. lato (unit 2, younger part of subunit 2a; sample 2009-D28; thickness about $30 \mathrm{~cm}$ ). The recognition of this zone is based on the presence of the index species Si. duplicata together with Si. sulcata and Si. carinthiaca, but without Si. praesulcata. Within the conodont assemblage we found Bi. stabilis, Po. communis communis, Po. communis carina, Po. longiposticus, Po. purus purus, and Ps. primus (with rare specimens of morphotype Ps. dentilineatus).

This interval contains only one sample; it is thus named only tentatively, with the association indicate Upper duplicata Zone by Sandberg et al. (1978) and Corradini $(2003,2008)$ [ = jii Zone of Becker et al.2016, who renamed the previously introduced hassi Zone with the index fossil Si. (Si.) hassi by Ji (1985)].

The younger parts of the Tournaisian succession (around $35 \mathrm{~cm}$ of the older part of subunit $2 \mathrm{a}$ and younger part of subunit 2b; Fig. 2) did not yield conodonts.

Lochriea commutata Zone (unit 2, younger part of subunit 2 b; sample 2008-DRZ 3; thickness about $15 \mathrm{~cm}$ ). - The lower boundary of this zone, which is close to the base of the early Viséan, is marked by the first appearance of Lo. commutata. The second feature is the presence of many species of Gnathodus, but without species of the $G n$. bilineatus group. The following conodont taxa are present: Bi. stabilis, Po. inornatus, Po. communis communis, Po. bischoffi, Gn. delicatus, Gn. pseudosemiglaber, Gn. punctatus, Gn. semiglaber, Ps. marginatus, Ps. pinnatus, Ps. triangulus and Ps. homopunctatus.

Gnathodus praebilineatus Zone (unit 3, subunit 3a; sample 2008-DRZ 2; thickness about $18 \mathrm{~cm}$ ). - The first appearance of Gn. praebilineatus (together with few Gn. bilineatus bilineatus) and the lack of species of Polygnathus are characteristics of this zone. The conodont association includes Lo. commutata, Gn. delicatus, Gn. pseudosemiglaber, Gn. semiglaber, Gn. austini, Gn. praebilineatus and Gn. bilineatus bilineatus.

Gnathodus bilineatus bilineatus Zone (unit 3, subunits $3 b$ and 3c; samples 2008-DRZ 1 and 2009-D27; thickness about $47 \mathrm{~cm}$ ). - The main characteristics of this zone are the high number of specimens of Gn. bilineatus bilineatus in the relation to those of Gn. praebilineatus and also the entry of the Gn. bilineatus remus and Gn. bilineatus romulus. Additionally, Lo. commutata, Gn. delicatus, Gn. semiglaber and $G n$. austini are associated in this zone.

The entire unit 4 with the thickness of $8.68 \mathrm{~m}$ is almost without conodonts. Only the stratigraphically youngest part yielded a poor conodont assemblage, but does not contain age indicative conodonts.

Lochriea nodosa Zone (unit 5, oldest part of subunit 5a; samples 2009-D11 to 2009-D09; thickness $70 \mathrm{~cm}$ ). - The latest Viséan zone, of which the lower boundary cannot be determined in the studied section, is recognized by the 


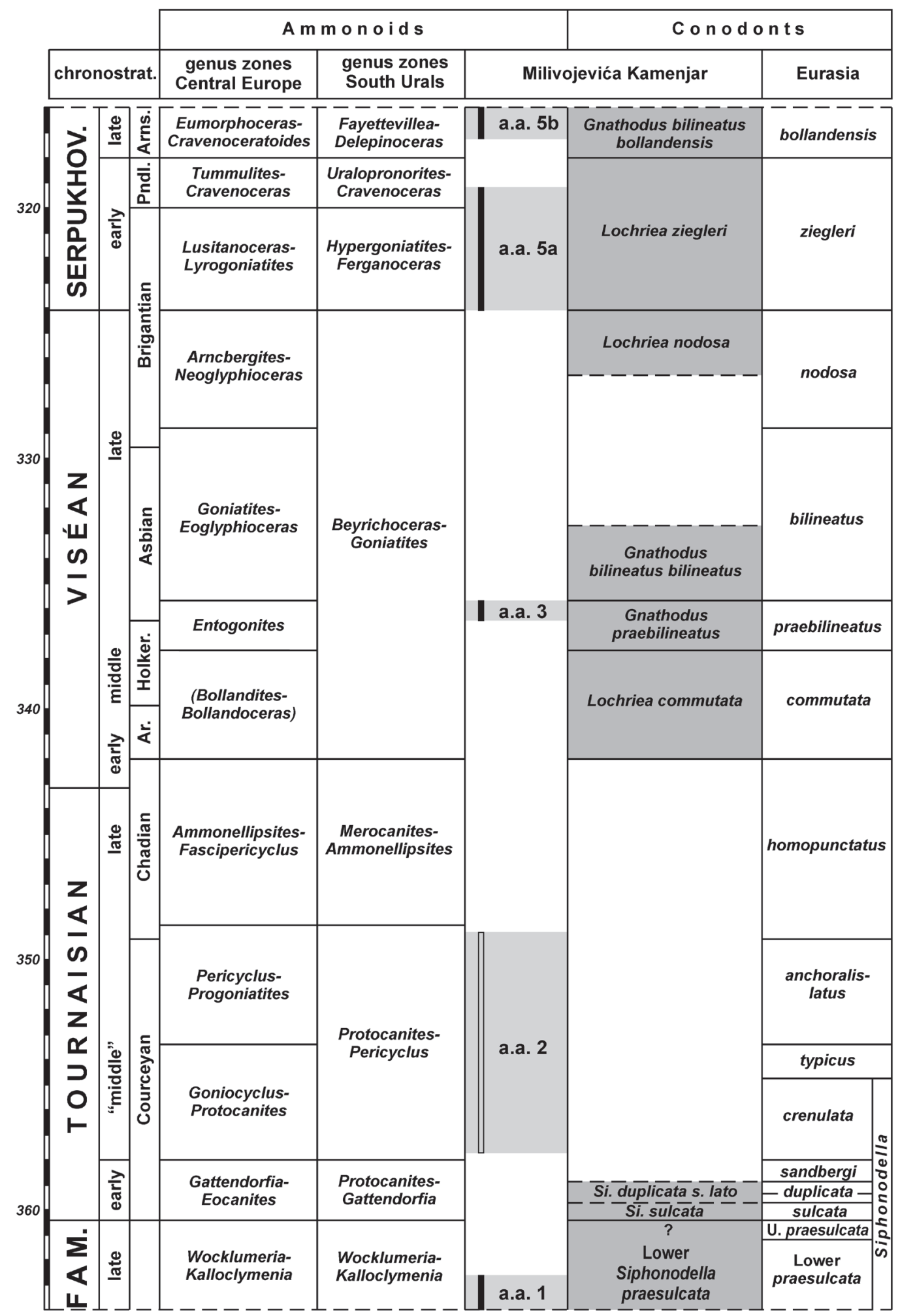

Figure 3. Latest Devonian to Serpukhovian stratigraphic scheme and biozonation with the indication of ammonoid and conodont records in the Milivojevića Kamenjar section. Ammonoid biostratigraphy after Ruzhencev \& Bogoslovskaya (1971) and Korn et al. (2007). Conodont biostratigraphy: latest Fammenian and early Tournaisian zones from Sandberg et al. (1978) and Corradini (2003, 2008); Viséan and early Serpukhovian zones from Somerville (2008) summarized on the several conodont zonal schemes by Belka (1985), Meischner \& Nemyrovska (1999), Nemyrovska (2005) and Nemyrovska et al. (2006). Abbreviations: a.a. - ammonoid assemblages separated in the studied section (Korn \& Sudar 2016); FAM. - Famennian; SERPUKHOV. - Serpukhovian; Ar. - Arundian; Holker. - Holkerian; Pndl. - Pendleian; Arns. - Arnsbergian. 
occurrence of Lo. nodosa, which is accompanied by Lo. commutata, Gn. girtyi and Gn. bilineatus bilineatus.

Lochriea ziegleri Zone (unit 5, middle and younger parts of subunit $5 \mathrm{a}$ and lower part of subunit 5b; samples 2008-DRZ A to 2008-DRZ E, 2009-D08 to 2009-D01, 2008-foot of rock, 2010-8 and 2010-7; thickness $2.82 \mathrm{~m}$ ).The lower boundary of this early Serpukhovian zone is defined by the first appearance datum (FAD) of Lo. ziegleri. Besides the zonal index species, other strongly ornamented species of Lochriea (Lo. senckenbergica and Lo. multinodosa) are also characteristic for this zone. In this conodont assemblage, the following species are identified besides the mentioned: Lo. mononodosa, Lo. nodosa (with rare specimens of morphotype Lo. nodocostata), Lo. commutata, Lo. scotiensis, Gn. girtyi and Gn. bilineatus bilineatus.

Gnathodus bilineatus bollandensis Zone. - The presence of this late Serpukhovian zone is in the stratigraphically youngest $0.85 \mathrm{~m}$ of the rock column (samples 2010-6 and 2010-5) on the basis of finding $G n$. bilineatus bollandensis. The accompanied association constitutes the same conodont species from the Lochriea lineage of the earlier zone.

The list demonstrates that evidence for a number of the Mississippian conodont zones is missing (Fig. 3). A longer gap ranges from the early Tournaisian to the base of the Viséan.

\section{Correlation of the conodont succession of the Milivojevića Kamenjar section with other regions}

The recognized associations in the Milivojevića Kamenjar section can be clearly separated in two intervals in terms of conodont biostratigraphy (Figs 2, 3); (1) the DevonianCarboniferous boundary interval and (2) the Viséan and Serpukhovian. Various conodont assemblages from the two intervals reveal the presence of nine conodont zones (Figs 2, 3). We did not sample material containing older Famennian conodont zones reported in previous research by Spasov \& Filipović (1967) and Scharfe (1977) because of outcrop limitations.

The first zonal complex, latest Famennian to earliest Tournaisian in age, is based on the phylogenetic development of early Siphonodella species (Sandberg et al. 1978; Corradini 2003, 2008, etc.); representatives of the Prothognathus fauna have not been found.

The second zonal complex is characterized by the subdivision based on the Gn. bilineatus group or, alternatively, on species of the Lochriea lineage, both ranging from the Viséan into the Serpukhovian. Between these two complexes occurs an about $35 \mathrm{~cm}$ thick interval within rock unit 2 without conodonts. This gap in the conodont record coincides with the younger part of the Tournaisian stage. Another gap in the conodont record spans a carbonate interval of more than eight metres thickness (rock unit 4). However, the identified gaps in the Milivojevića Kamenjar fossil record are not an obstacle for the recognition of a rather precise biostratigraphic conodont zonation (Fig. 2).

The sequence of the early Siphonodella zones, i.e. of the Devonian-Carboniferous boundary interval, recognized in the Milivojevića Kamenjar section can be correlated with many areas in Europe, e.g. Rhenish Mountains, Montagne Noire and Pyrenees (Southern France), Cantabrian Mountains (Spain), Carnic Alps (Austria), Sardinia (Italy) etc.; Asia, e.g. Urals, Kazakhstan, China, etc.; and also from North America, e.g. Rocky Mountains, Great Basin, Mississippi Valley. For further information, see papers by Ziegler et al. (1974), Sandberg et al. (1978), Ziegler \& Sandberg (1984), Over (1992), Corradini

Figure 4. Late Devonian and Mississippian conodonts from the Milivojevića Kamenjar section of the Jadar Block (Družetić, NW Serbia). Famennian, Lower Si. praesulcata Zone (A-G, I-P, Y-Z); Tournaisian, Si. sulcata Zone (H, Q, V, X); Tournaisian, Si. duplicata Zone s. lato (R-U, $\mathrm{XW}-\mathrm{XY}$ ); Viséan, Lo. commutata Zone (W, XZ). All are upper views, only D is lateral view. Scale bars for A-F, I-L, N-P, R-Z, XW, XZ are $100 \mu \mathrm{m}$; for $\mathrm{G}, \mathrm{H}, \mathrm{M}, \mathrm{Q}, \mathrm{XY}$ are $200 \mu \mathrm{m}$. $-\mathrm{A}-\mathrm{C}$ - Palmatolepis gracilis gracilis Branson \& Mehl; A - specimen 100RGFMS from sample 2009-D32; B - specimen 160RGFMS from sample 2010-2; C - specimen 24RGFMS from sample 2008-DRZ 4. • D - Palmatolepis gracilis sigmoidalis Ziegler, specimen 26RGFMS from sample 2008-DRZ 4. • E, F - Palmatolepis gracilis expansa Sandberg \& Ziegler; E - specimen 107RGFMS from sample 2009-D30; F - specimen 31RGFMS from sample 2008-DRZ 4. • G - Bispathodus spinulicostatus (Branson), specimen 162RGFMS from sample 2010-2. • H - Bispathodus aculeatus (Branson \& Mehl), specimen 104RGFMS from sample 2009-D29. • I - Bispathodus bispathodus Ziegler, Sandberg \& Austin, specimen 142RGFMS from sample 2008-DRZ 4. - J - Bispathodus costatus (Branson), specimen 102RGFMS from sample 2009-D32. • K - Bispathodus stabilis (Branson \& Mehl), specimen 50RGFMS from sample 2008-DRZ 4. • L - Bispathodus ultimus (Bischoff) morphotype Bispathodus ziegleri (Rhodes, Austin \& Druce), specimen 112RGFMS from sample 2009-D30. • M - Bispathodus ultimus (Bischoff), specimen 119RGFMS from sample 2009-D30. • N - Polygnathus inornatus Branson, specimen 156RGFMS from sample 2010-4. • O, P - Siphonodella preasulcata Sandberg; O - specimen 115RGFMS from sample 2009-D30; P - specimen 52RGFMS from sample 2008-DRZ 4. • Q, R - Siphonodella sulcata (Huddle); Q - specimen 120RGFMS from sample 2009-D29; R - specimen 118RGFMS from sample 2009-D28. $・$ S - Siphonodella carinthiaca Schönlaub, specimen 125RGFMS from sample 2009-D28. • T, U - Siphonodella duplicata (Branson \& Mehl); T - specimen 126RGFMS; U - specimen 127RGFMS. Both from sample 2009-D28. • V - Polygnathus purus subplanus Voges, specimen 165RGFMS from sample 2010-1. $\bullet$ W, X - Polygnathus purus purus Voges; W - specimen 40RGFMS from sample 2008-DRZ 3; X - specimen 122RGFMS from sample 2009-D29. • Y, Z - Polygnathus communis communis Branson \& Mehl; Y - specimen 117RGFMS from sample 2009-D30; Z - specimen 105RGFMS from sample 2009-D31. • XW - Polygnathus communis carina Hass, specimen 128RGFMS from sample 2009-D28. XY - Polygnathus longiposticus Branson \& Mehl, specimen 131RGFMS from sample 2009-D28. XZ - Pseudognathodus homopunctatus (Ziegler), specimen 42RGFMS from sample 2008 -DRZ 3. 


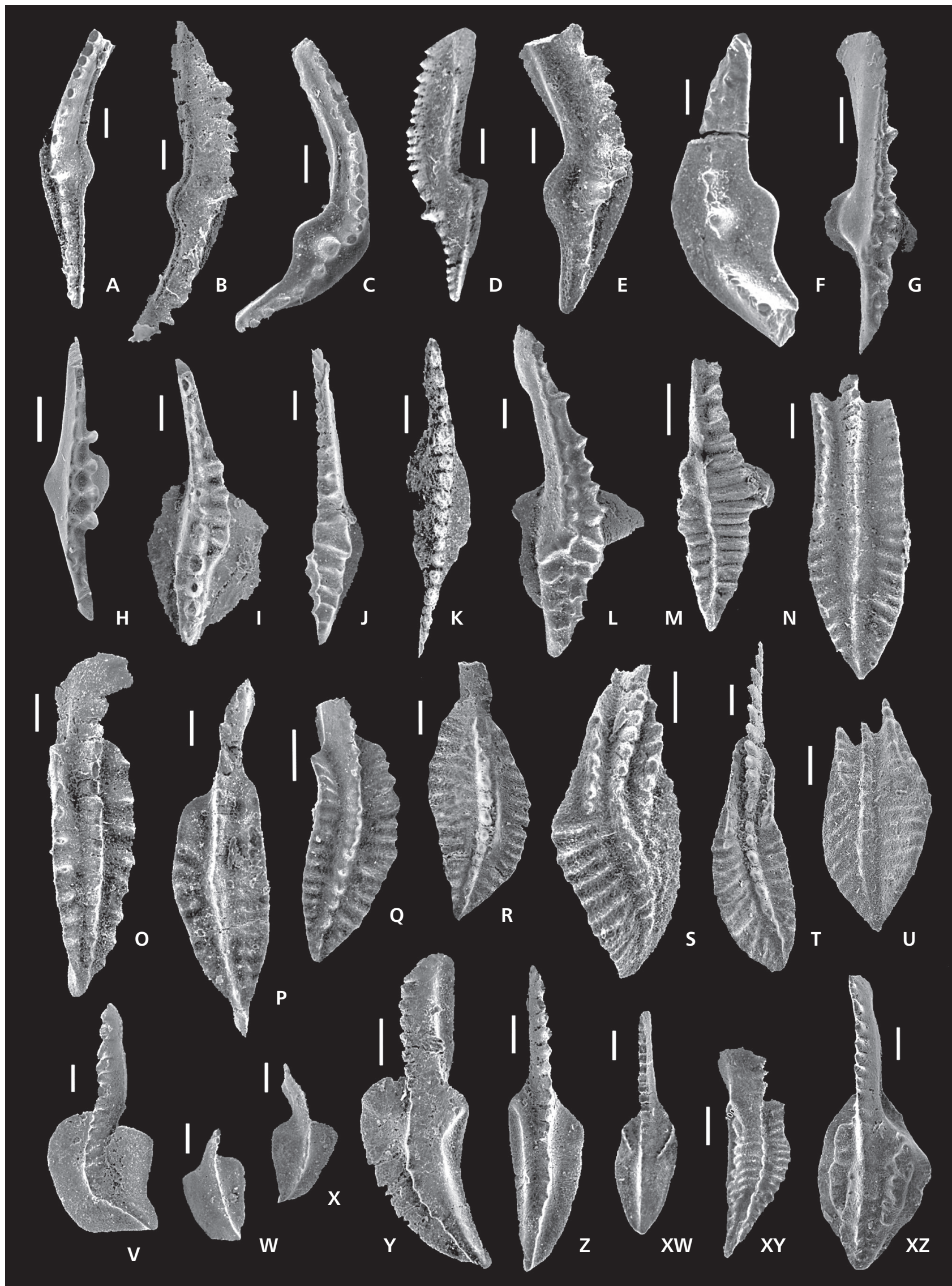


(2003, 2008), Kaiser et al. (2009), Corradini et al. (2011, 2016), Kalvoda et al. (2015), Mossoni et al. (2015) and Spalletta et al. (2017). In the studied Milivojevića Kamenjar section, the interval of Devonian-Carboniferous boundary occurs in a continuous limestone succession, not interrupted by strata indicating the Hangenberg Event.

Our results may contribute to the discussion of the ViséanSerpukhovian boundary. Based on the first occurrence datum (FOD) and the vertical distribution of zonal index species, six conodont zones within the late Viséan-Serpukhovian interval are distinguished. It begins with the Viséan $L o$. commutata, Gn. praebilineatus and Gn. bilineatus bilineatus zones and continues to the latest Viséan Lo. nodosa Zone and finally the Serpukhovian Lo. ziegleri and Gn. bilineatus bollandensis zones. Within this stratigraphic interval, three levels are most important for interregional correlation, (1) the entry of Lo. commutata, (2) the appearance of the species of the Gn. bilineatus group and (3) the first occurrence of coarsely ornamented species of Lochriea, particularly Lo. ziegleri and Lo. senckenbergica.

Lochriea commutata and all zonal species of the Gn. bilineatus group are cosmopolitan taxa, whose first occurrences have been used as the most suitable zonal markers for establishing various zones in many Eurasian and North American basins (for more details, see citations in Nemyrovska 2005, p. 30-32). In contrast, Lo. ziegleri as well as all the other coarsely ornamented species of Lochriea have not been found in North America (Nemyrovska 2005); the zonation based on the species from this part of Lochriea lineage is recognized only in Eurasian areas. Especially in the last fifteen years, the first appearance datum (FAD) of Lo. ziegleri has been suggested as zonal index for the Viséan-Serpukhovian boundary (e.g. Nikolaeva et al. 2002, 2009a, b, 2014; Wang \& Qi 2003; Nemyrovska 2005; Qi \& Wang 2005).

The Viséan-Serpukhovian boundary beds have been investigated in detail in the Verkhnyaya Kardailovka section (South Urals, Russia). Multiple ammonoid occurrences have been found throughout the late Viséan and Serpukhovian levels of the section; they were correlated with a good conodont and foraminiferal record. These were the reasons to propose this locality as a potential GSSP candidate for the Viséan-Serpukhovian boundary (e.g. Nikolaeva et al. 2009b, 2014; Pazukhin et al. 2010).

The Milivojevića Kamenjar section is particularly interesting for the discussion of the Viséan-Serpukhovian boundary. The latest Viséan-Serpukhovian part of the section and the Viséan-Serpukhovian boundary is well-documented with the first appearance of Lo. ziegleri. In this respect it closely resembles the Verkhnyaya Kardailovka section.

\section{Correlation of the conodont and ammonoid zonations}

The Milivojevića Kamenjar section offers the opportunity to study conodonts and ammonoids in a simultaneous attempt. This is particularly important for the stratigraphically younger horizons in the outcrop, the latest Viséan and Serpukhovian interval (Fig. 3).

Unfortunately, the transition from the Lo. nodosa Zone to the Lo. ziegleri Zone, i.e. the proposed Viséan-Serpukhovian boundary, cannot be determined with ammonoid findings. The interval belonging to the Lo. nodosa Zone did not yield ammonoids, while the Lo. ziegleri Zone contains a number of ammonoid horizons which all belong in the HypergoniatitesFerganoceras and Uralopronorites-Cravenoceras genus zones. Of the in-situ collected ammonoid samples (Korn \& Sudar 2016), particularly sample 2009-C was productive. It yielded species, which according to Ruzhencev \& Bogoslovskaya (1971) occur in their $\mathrm{Nm}_{1}$ a (e.g. Dombarites falcatoides, Platygoniatites omniliratus, Ophilyroceras tersum zones) but also in the $\mathrm{Nm}_{1} \mathrm{~b}_{1}$ (e.g. Dombarites liratus, Lusitanites concavus, Lyrogoniatites tener zones). This discrepancy cannot be explained at the moment.

In the more complete Verkhnyaya Kardailovka section (South Urals), ammonoid findings have been correlated with the conodont succession (Nikolaeva et al. 2009b, 2014;

Figure 5. Conodonts from the Milivojevića Kamenjar section in the Jadar Block (Družetić, NW Serbia). Mississippian, Tournaisian, Si. sulcata Zone (A, D); Viséan, Lo. commutata Zone (B, C, O); Viséan, Gn. praebilineatus Zone (K, N, S); Viséan, Gn. bilineatus bilineatus Zone (G-J, L, M); Viséan, Lo. nodosa Zone (F, T); Serpukhovian, Lo. ziegleri Zone (E); Serpukhovian, Gn. bilineatus bollandensis Zone (P-R). All are upper views. Scale bars for A-D, G-I, L, N, O, S, T are $100 \mu \mathrm{m}$; for E, F, J, K, M, P-R are $200 \mu \mathrm{m}$. A - Pseudopolygnathus primus Branson \& Mehl morphotype Pseudopolygnathus dentilineatus Branson, specimen 170RGFMS from sample 2010-1. • B - Pseudopolygnathus marginatus (Branson \& Mehl), specimen 45RGFMS from sample 2008-DRZ 3. • C - Pseudopolygnathus pinnatus (Voges), specimen 46RGFMS from sample 2008-DRZ 3. D - Pseudopolygnathus primus Branson \& Mehl, specimen 175RGFMS from sample 2010-1. • E, F - Gnathodus bilineatus bilineatus (Roundy); E - specimen 170RGFMS from sample 2010-8; F - specimen 136RGFMS from sample 2009-D11. • G, H - Gnathodus bilineatus remus Meischner \& Nemyrovska; G - specimen 71RGFMS; H - specimen 72RGFMS. Both from sample 2008-DRZ 1. • I, J - Gnathodus bilineatus romulus Meischner \& Nemyrovska; I - specimen 75RGFMS; J - specimen 77RGFMS. Both from sample 2008-DRZ 1. $\bullet$ K, L - Gnathodus pseudosemiglaber Thompson \& Fellows; K - specimen 68RGFMS from sample 2008-DRZ 2; L - specimen 82RGFMS from sample 2008-DRZ 1. • M, N - Gnathodus praebilineatus Belka; M - specimen 135RGFMS from sample 2009-D27; N - specimen 69RGFMS from sample 2008-DRZ 2. • O - Polygnathus bischoff Rhodes, Austin \& Druce, specimen 150RGFMS from sample 2008-DRZ 3. • P-R - Gnathodus bilineatus bollandensis Higgins \& Bouckaert; P - specimen 194RGFMS from sample 2010-6; Q - specimen 198RGFMS; R - specimen 200RGFMS. Both (Q, R) from sample 2010-5. $\mathrm{S}$ - Gnathodus delicatus Branson \& Mehl, specimen 51RGFMS from sample 2008-DRZ 2. • T - Gnathodus girtyi Hass, specimen 138RGFMS from sample 2009 -D11. 


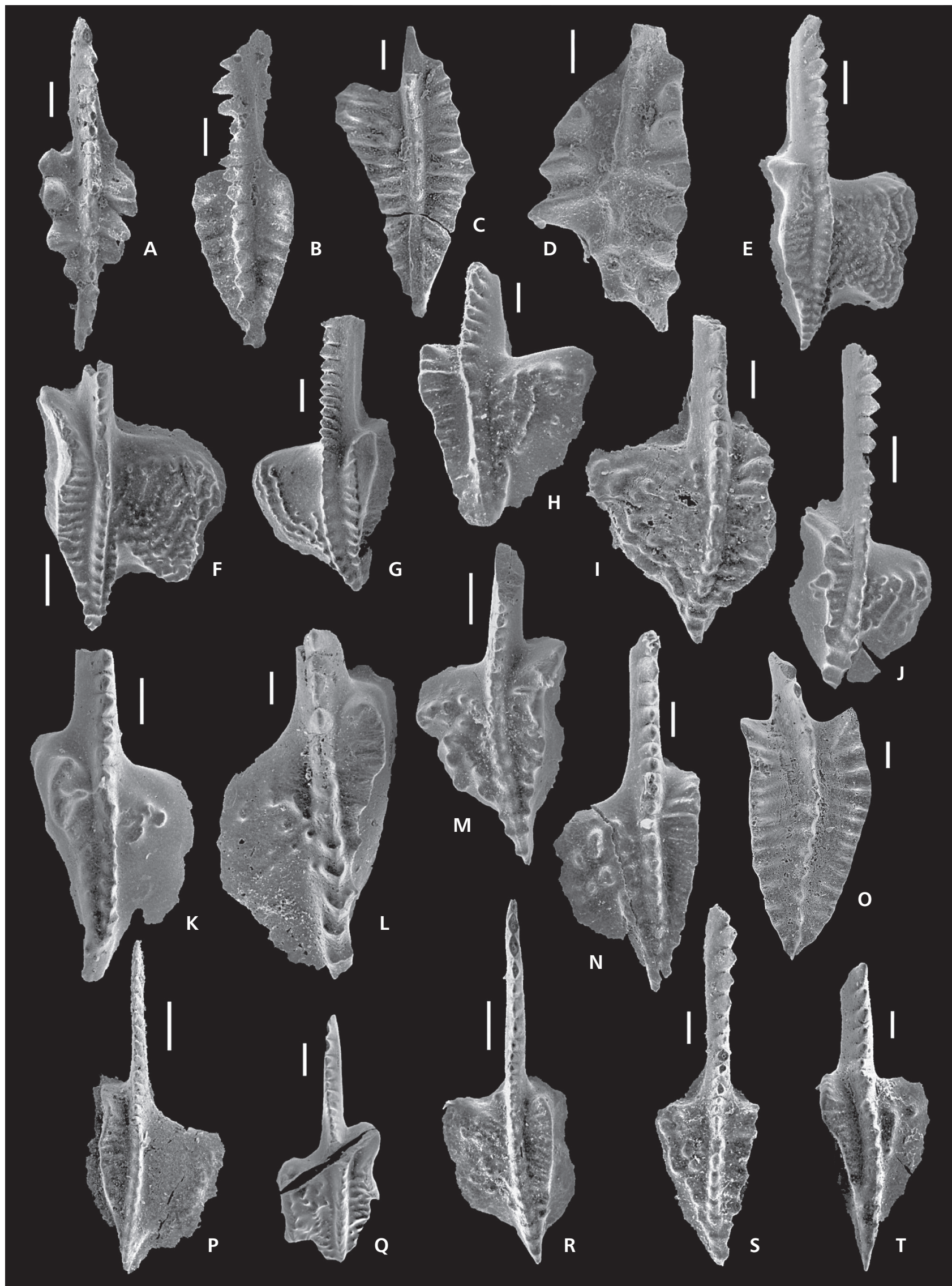


Pazukhin et al. 2010; Nikolaeva 2013a, b). According to these studies, the first occurrence of Lo. ziegleri lies within the $\mathrm{Nm}_{1}$ a ammonoid zone (in the terminology of Ruzhencev \& Bogoslovskaya 1971) with Neogoniatites milleri at this place occurring already in the Lo. mononodosa Zone and Dombarites parafalcatoides appearing in the Lo. nodosa Zone and passing the Viséan-Serpukhovian boundary. These data confirm the results gained from the Dombar Hill section of Kazakhstan (Nikolaeva et al. 2009a).

However, the Lo. nodosa Zone has a thickness of only 0.50 metres in the Verkhnyaya Kardailovka section (Nikolaeva et al. 2014). This is surprisingly thin, as the zone in other regions possesses a much larger thickness, such as eight metres in the Naqing section of Guizhou (Qi \& Wang 2005; Qi et al. 2009, 2014), however this is a calciturbidite section where larger thicknesses are expectable. According to studies in the Rhenish Mountains (Meischner 1962, 1970; Meischner in Skompski et al. 1995), the Lo. nodosa Zone has, also in calciturbidites, a thickness of at least 20 metres and contains several ammonoid zones (Korn 1996, 2006). These sections are being newly investigated for their conodont and ammonoid succession (Wang et al. 2017, 2018).

Unfortunately, neither the Milivojevića Kamenjar section nor the Verkhnyaya Kardailovka section yielded ammonoid faunas between the occurrences with Goniatites-dominated assemblages and Dombarites-dominated assemblages, i.e. the interval in that equivalents of the Central and Western European Arnsbergites-Hibernicoceras-Paraglyphioceras assemblages do occur.

\section{Carbonate microfacies and depositional environment}

The carbonate microfacies of the investigated section are determined and described using the classification systems for carbonate sedimentary rocks and the standard microfacies (SMF) types and facies zones (FZ) as reviewed by Flügel (2004).

Five microfacies are recognized based on compositional and structural properties (Figs 7-9). In the text microfacies are described, like conodont zones and how is present in Fig. 2, in the stratigraphic order from the oldest to the youngest part of the column.

Microfacies 1 (fine-bioclastic wackestone; biomicrite). - Recognized in the interval of samples 2008-DRZ 4, 2009D32 to 2009-D28, and 2010-4 to 2010-1, of the whole unit 1 and subunit $2 \mathrm{a}$ (measured thickness of $2.75 \mathrm{~m}$ ). Moderatelysorted biomicrite consists of mottled micritic matrix with abundant thin-shelled bioclasts. Characteristic microfossils are small entomozoan ostracods with highly spinose ornamentation. Other skeletal grains are fragmented filaments of pelagic bivalves, thin-shelled juvenile ammonoids, trilobite and crinoid fragments and rare small gastropods. Compaction is indicated by interconnected network of thin stylolites and sets of calcite veins associated with dolomitization. Dolomite occurs in very fine diffuse aphanocrystalline ferroan (ankeritic) type. The same type crystallized in walls of moldic pores and vugs. Larger voids are cemented with blocky sparite (Fig. 7A, B).

Microfacies 1 corresponds to SMF 9, deposited in an open-marine deep-shelf environment with pelagic fauna (FZ 2).

Microfacies 2 (partially dolomitized condensed ammonoid rudstone; biosparite to poorly-washed biomicrite to sparite; burial diagenesis has transformed a depositional rudstone into a diagenetic condensed rudstone). - Occurs in samples 2008-DRZ 3 to 2008-DRZ 1 of whole subunit $2 b$ and the subunits $3 \mathrm{a}, 3 \mathrm{~b}$ (thickness of $0.68 \mathrm{~m}$ ).

The average size of densely packed ammonoid conchs is $3.5 \mathrm{~mm}$ and ranging up to $10 \mathrm{~mm}$, resulting in rudstone fabric. Besides ammonoids, there are very few other skeletal grains, represented by molluscan shell fragments and rare trilobite fragments. Most of grain contacts are sutured. The rock exhibits both, syndepositional and diagenetic skeletal concentration by compaction and pressure solution. Infillings of shells, as well as shelter pores exhibit geopetal structures, indicating inverse orientation. High primary fabric-selective porosity, represented by shelter, intra- and inter-particle porosity is enlarged by secondary biomoldic

Figure 6. Conodonts from the Milivojevića Kamenjar section in the Jadar Block (Družetić, NW Serbia). Mississippian, Viséan, Lo. commutata Zone (B); Viséan, Gn. praebilineatus Zone (A, D); Viséan, Gn. bilineatus bilineatus Zone (C); Viséan, Lo. nodosa Zone (I); Serpukhovian, Lo. ziegleri Zone (E-H, J, K, M-P); Serpukhovian, Gn. bilineatus bollandensis Zone (L, Q). All are upper views. Scale bars for all are $100 \mu \mathrm{m}$. $・$ A, B - Gnathodus semiglaber Bischoff; A - specimen 56RGFMS from sample 2008-DRZ 2; B - specimen 53RGFMS from sample 2008-DRZ 3. - C, D - Lochriea commutata (Branson \& Mehl); C - specimen 80RGFMS from sample 2008-DRZ 1; D - specimen 60RGFMS from sample 2008-DRZ 2. • E - Lochriea scotiensis (Globensky), specimen 91RGFMS from sample 2008-DRZ A. • F, G - Lochriea mononodosa (Rhodes, Austin \& Druce); F-specimen 93RGFMS from sample 2008-DRZ A; G - specimen 99RGFMS from sample 2008-DRZ C. • H, I - Lochriea nodosa (Bischoff); H - specimen 175RGFMS from sample 2010-8; I - specimen 140RGFMS from sample 2009-D11. • J - Lochriea nodosa (Bischoff) morphotype Lochriea nodocostata (Pazukhin \& Nemirovskaya), specimen 102RGFMS from sample 2008-foot of rock. • K, L-Lochriea multinodosa Wirth; K - specimen 180RGFMS from sample 2010-8; L - specimen 205RGFMS from sample 2010-5. M, N - Lochriea ziegleri Nemirovskaya, Perret \& Meischner; M - specimen 94RGFMS from sample 2008-DRZ A; N - specimen 187RGFMS from sample 2010-8, • O-Q - Lochriea senckenbergica Nemirovskaya, Perret \& Meischner; O - specimen 98RGFMS from sample 2008-DRZ B; P - specimen 190RGFMS from sample 2010-8; Q - specimen 208RGFMS from sample 2010-5. 


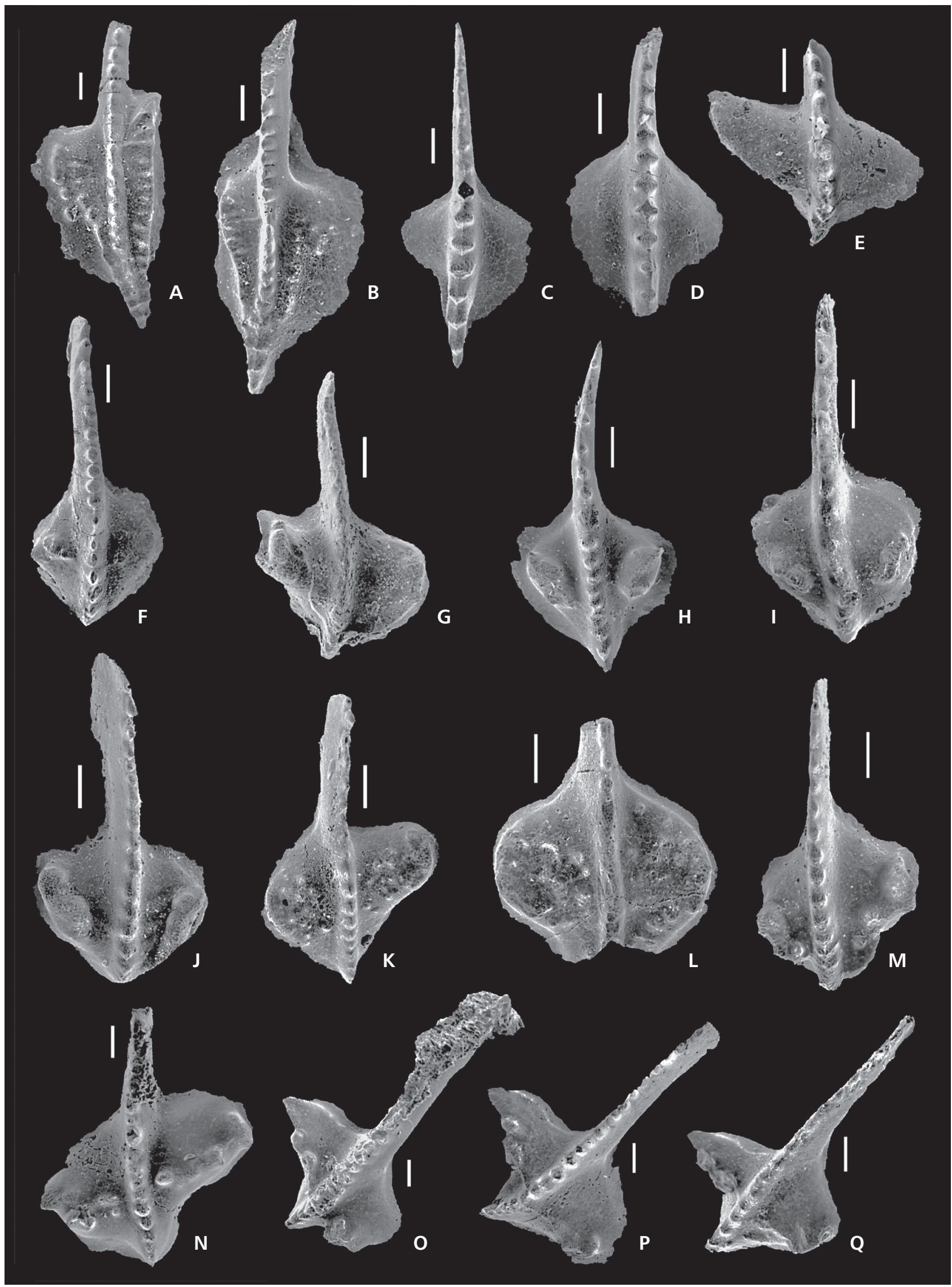



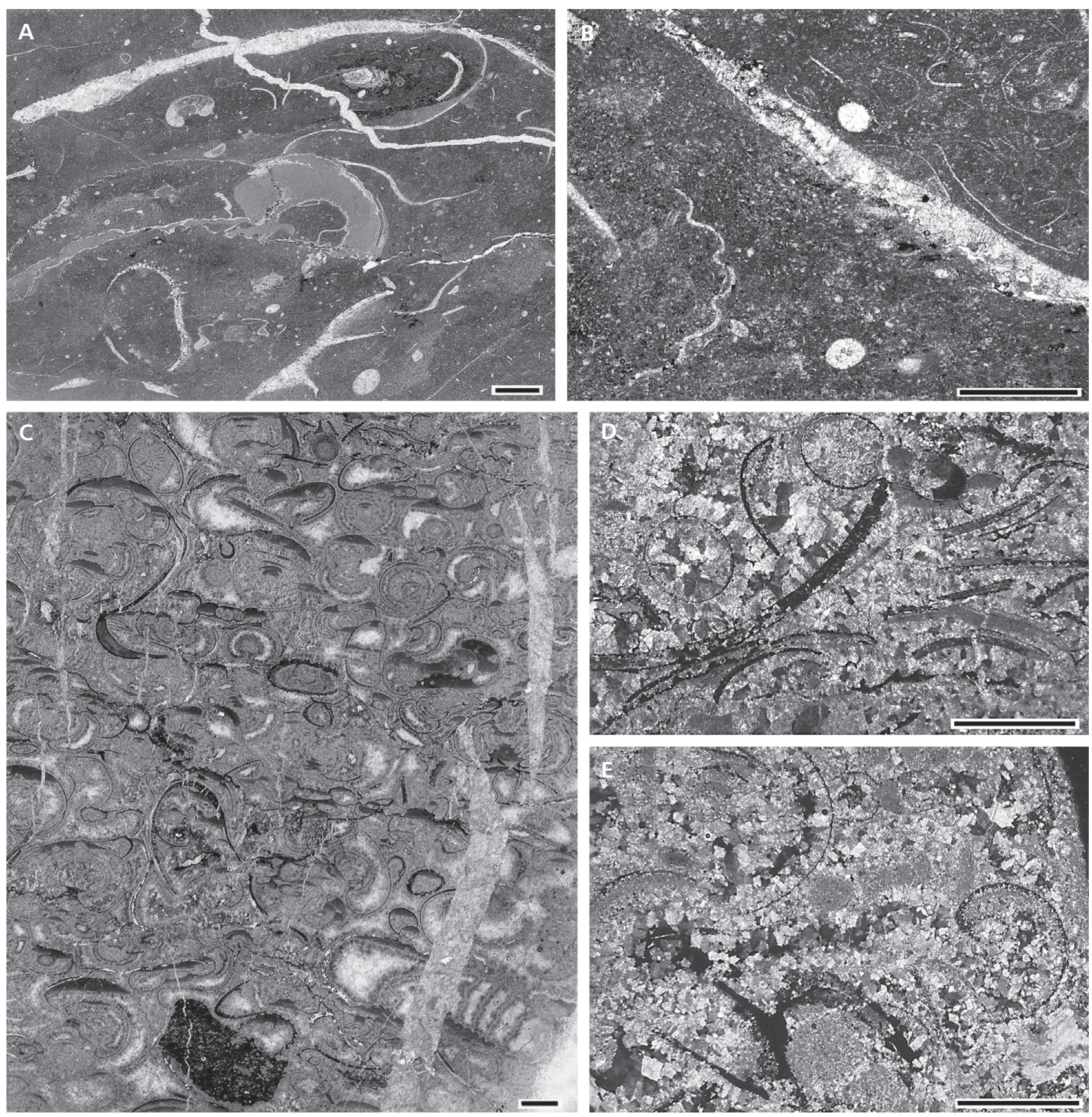

Figure 7. Microfacies types in Milivojevića Kamenjar section in the Jadar Block (Družetić, NW Serbia). • A, B - microfacies 1: fine-bioclastic wackestone with mottled micritic matrix and thin-shelled bioclasts; A - larger grains are juvenile ammonoids, trilobites and crinoid ossicles. Sample 2009-D30; B - finer grains are entomozoan ostracods and pelagic bivalves. Dolomite occurs in fine diffuse aphanocrystalline ferroan (ankeritic) type. Sample 2009-D30. - C-E - microfacies 2: partially dolomitized condensed rudstone with well-sorted, densely packed ammonoids in sparite and poorly-washed micrite; $\mathrm{C}$ - infillings of shells and shelter pores exhibit inverse geopetal structures. Partial dolomitization with coarse euhedral and fine diffuse anhedral to aphanocrystalline ankeritic dolomite crystals. Most grain contacts are sutured. Sample 2008-DRZ 1/4; D - open moldic porosity in most of skeletal grains is preserved due to dark micritic envelopes caused by microbial microboring (indicated by irregular outlines), partial dissolution of aragonitic shells and associated recrystallization resulting in residual micrite. Micritic envelopes are more resistant to dissolution but prone to selective dolomitization. Sample 2008-DRZ 1/3, crossed polars; E - thin rims of marine isopachous radial fibrous cement and late diagenetic recrystallized drusy-mosaic cement. Sample 2008-DRZ 1/2, crossed polars. Scale bars $=2 \mathrm{~mm}$.

solution and vuggy porosity, and intercrystalline porosity due to dolomitization. Open moldic porosity is present in most of skeletal grains. The cement exhibits several generations.
Preserved are thin rims of marine isopachous radial fibrous cement and late diagenetic recrystallized drusy-mosaic cement (Fig. 7C-E). 

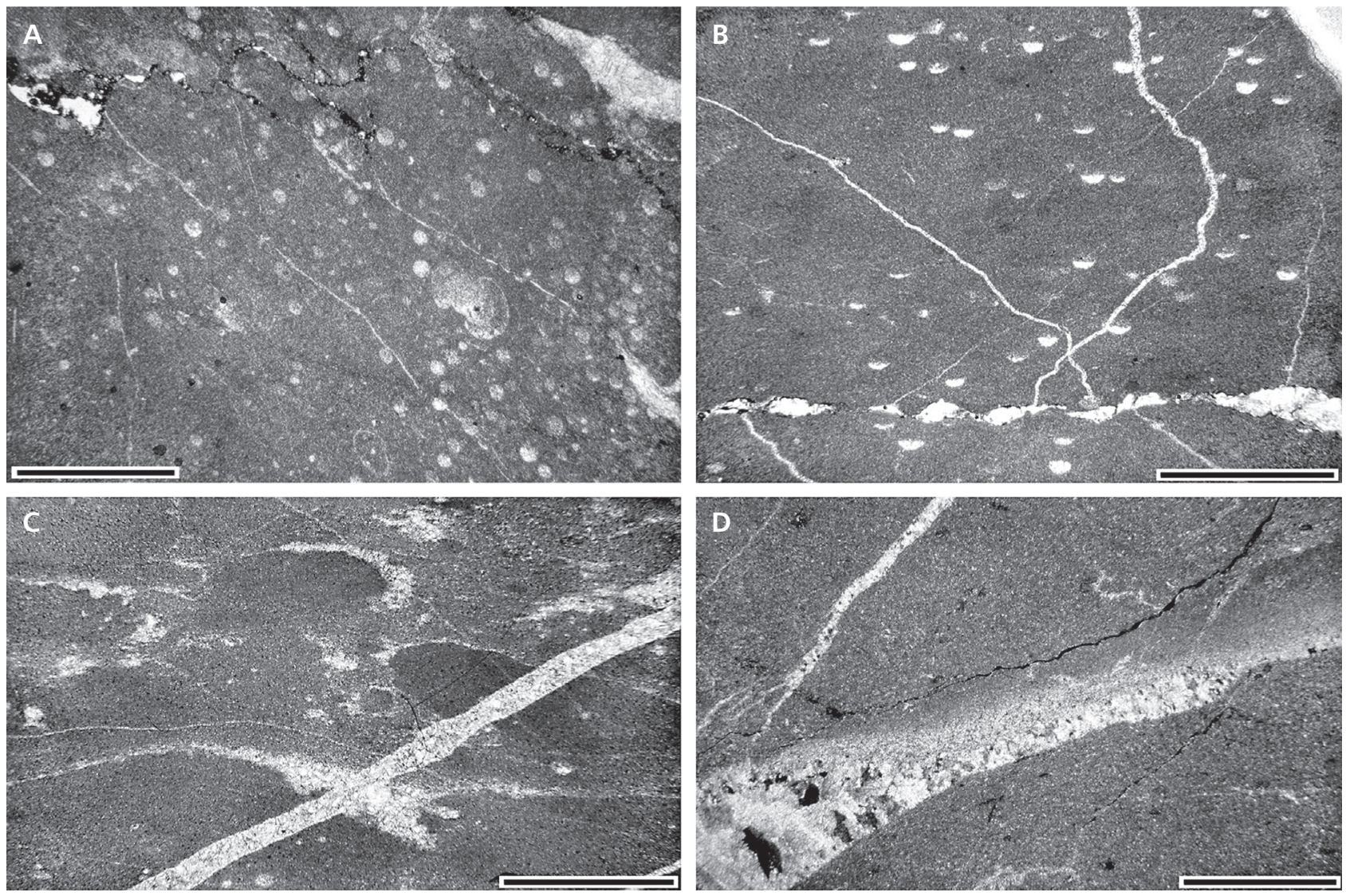

Figure 8. Microfacies types in Milivojevića Kamenjar section in the Jadar Block (Družetić, NW Serbia) (continued). A-D - microfacies 3: burrowed fine-bioclastic mud- to wackestone; A - abundant calcispheres in bioturbated micritic matrix. Accompanied are sponge spicules, small ostracods and juvenile ammonoids. Sample 2009-D09/2; B - calcispheres with geopetal infillings indicate inverse orientation. Sample 2009-D21; C - mottled micrite and an uneven distribution of calcispheres indicate burrowing. Sample 2009-D24; D - several crosscutting calcite veins exhibit inverse geopetal infilling with graded micrite and two generations of sparry cement. Sample 2009-D10, crossed polars. All images are oriented as sampled in the section. Scale bars $=2 \mathrm{~mm}$.

Microfacies 2 corresponds to SMF 5, deposited in an open-marine platform slope environment (FZ 4).

Microfacies 3 (burrowed fine-bioclastic mud- to wackestone; biomicrite). - Recognized in samples 2009-D26 to 2009-D09 of the whole unit 4 and uppermost part of subunit 5a (thickness of $9.38 \mathrm{~m}$ ). The most characteristic bioclasts are calcispheres, sponge spicules, fragmented filaments of pelagic bivalves, entomozoan ostracods and peloids. The term calcispheres is here used as a general term referred to spherical calcitic microfossils, commonly occurring in large numbers. The moderately thick densemicritic wall without perforations or openings and hollow interior (indicated by geopetal infillings) speak more in favor of genuine calcispheres (algal cysts). But because of the co-occurrence with calcitized sponge spicules and other pelagic fossils, they are more likely to be recrystallized radiolarians. Larger grains are juvenile ammonoids, crinoid ossicles as well as fragments of trilobites and gastropods. Compaction is indicated by an interconnected network of stylolites and sets of calcite veins. Replacement of micrite with iron-rich fine-crystalline dolomite mostly occurs in bioclasts and along stylolites (Fig. 8).

Microfacies 3 corresponds to SMF 1, deposited in an open-marine deep-shelf environment (FZ 2).

Microfacies 4 (ammonoid rudstone with bioclastic wacke- to packstone matrix; packed biomicrite). - Occurs in samples 2008-DRZ A, 2008-DRZ B, 2008-DRZ C and 2009-D08 to 2009-D06, of the middle part of subunit 5a (thickness of $0.64 \mathrm{~m})$.

Numerous thin-shelled ammonoids, 3 to $6 \mathrm{~mm}$ big, with ornamented surfaces are packed in micritic matrix. Most shells exhibit upside-down geopetal infilling and cementation with blocky calcite. Infilling micritic sediment in the chambers is the same as the enclosing matrix indicating infilling of shells on the surface before burial. The ammonoids are accompanied by fragmented pelagic bivalve filaments. Densely packed coquina with the divergent orientation of shells, good preservation of skeletal elements, bimodal 
sorting (complete shells and debris), and absence of signs of abrasion or bioerosion indicate high-energy event deposition (tempestite). Concentration of bioclasts is increased by both, mechanical and chemical compaction resulting in the condensed fabric. Mechanical compaction is reflected in shears and fractures and the chemical one, occurred through selective pressure solution, is shown by stylolite seams and irregular grain boundaries (Fig. 9A-C).

Microfacies 4 corresponds to SMF 8, deposited in an open-marine deep-shelf setting (FZ 2).

Microfacies 5 (burrowed fine-bioclastic wackestone; biomicrite). - Recognized in the samples 2008-DRZ D, 2008-DRZ E and 2009-D05 to 2009-D01, of the lower part of the subunit $5 \mathrm{a}$ (thickness of $1.46 \mathrm{~m}$ ).

Mottled, burrowed micrite with voids, filled with radial fibrous and coarse blocky cement. Sparse small bioclasts are represented by fragmented filaments of bivalves, thinshelled (juvenile) ammonoids, ostracods, sponge spicules, and calcispheres. The calcispheres are likely to be altered (calcitized) radiolarians, since sponge spicules are also recrystallized. Rare are small intraclasts. Compaction is indicated by interconnected network of irregularly shaped stylolites associated with calcite veins. Micrite is partially replacemed with iron-rich fine-crystalline dolomite (Fig. 9D, E).

Microfacies 5 corresponds to SMF 9, deposited in an open-marine deep-shelf environment with pelagic fauna (FZ 2).

Fine bioclastic mudstone and wackestone (MF 1, MF 3 and MF 5) dominate in the Milivojevića Kamenjar section with two horizons of coarser-grained ammonoid rudstone and packstone (MF 2 and MF 4).

The two coarser-grained microfacies types exhibit both syndepositional and diagenetic skeletal concentration by compaction and pressure solution. Deep burial diagenesis is indicated by spar cement enriched in iron and partial dolomitization with coarse euhedral and very fine diffuse anhedral to aphanocrystalline ferroan (ankeritic) dolomite crystals. High primary fabric-selective porosity in rudstone, represented by shelter, intra- and inter-particle porosity is enlarged by secondary biomoldic solution and vuggy porosity, and intercrystalline porosity due to dolomitization.

The recorded microfacies types and fossil assemblages as well as sedimentological fabrics (e.g. nodular bedding) are all characteristic of deep-marine environments with only minor shifts in facies zones from deep platform slope to open-marine deep-shelf. Densely packed coquinas (MF 2 and MF 4) with the divergent orientation of shells indicate highenergy event deposition (tempestite). Supporting evidences are good preservation of skeletal elements, bimodal sorting (complete shells and debris) and absence of abrasion or bioerosion.

\section{Conclusions}

The study of the Milivojevića Kamenjar site in Družetić (NW Serbia) provides the best documented Mississippian fossil succession in the Balkan Peninsula. The conodont inventory of the section reveals that nine zones (one only tentatively) between the late Famennian Lower $S i$. praesulcata Zone and the late Serpukhovian Gn. bilineatus bollandensis Zone are recognized. They can be correlated with ammonoid assemblages from the late Famennian to the late Serpukhovian age (Korn \& Sudar 2016); particularly the two late Viséan assemblages containing Entogonites and two latest Viséan-Serpukhovian assemblages containing Dombarites and Proshumardites.

The Milivojevića Kamenjar section is particularly important for drawing the Viséan-Serpukhovian boundary. The first occurrence of Lo. ziegleri and Lo. senckenbergica is paralleled by a rather diverse ammonoid assemblage with Dombarites falcatoides, Do. liratus, Platygoniatites omniliratus, Pl. molaris as well as species of the genera

Figure 9. Microfacies types in Milivojevića Kamenjar section in the Jadar Block (Družetić, NW Serbia) (continued). A-C - microfacies 4: bioclastic rudstone with thin-shelled ammonoids packed in micritic matrix. Most shells exhibit upside-down geopetal structures with internal micrite and cementation with blocky calcite. Ammonoids are accompanied by fragmented pelagic bivalve filaments; A - densely packed coquina with shells, exhibiting upside-down geopetal infilling with graded internal micrite and cementation with blocky calcite. Shears and fractures reflect mechanical compaction. Stylolite seams and irregular grain boundaries indicate chemical compaction, occurred through selective pressure solution. Thicker veins exhibit at least two generations of cementation with blocky calcite. Sample 2009-D06/3; B - distinct irregular microfacies boundary of high-energy fabric of the coquina layer and the low-energy mudstone points to rapid changes in the depositional environment. Sample 2009-D07; C - the thicker, originally aragonitic shells have been replaced by coarse-grained calcite. Some parts are completely obliterated, others exhibit several cement generations and infilling by micritic sediment. In large shelter pores are several generations of marine isopachous fibrous and late diagenetic recrystallized blocky calcite cements. Samples 2008-DRZ B/1. • D, E - microfacies 5: burrowed fine-bioclastic wackestone with mottled micritic matrix and voids filled with radial fibrous and coarse blocky cement. Sparse fragmented filaments of bivalves, thin-shelled (juvenile) ammonoids, ostracods, sponge spicules, and calcispheres; D - interconnected network of irregularly shaped stylolites associated with calcite veins. Replacement of micrite with iron-rich fine-crystalline dolomite occurred mostly in bioclasts and along stylolites. Sample 2009-D01; E - mottled micrite, microsparite and peloidal micrite exhibiting clotted fabric. Calcispheres show geopetal internal sediment fill, indicating inverse orientation. Peloids originate from reworking of weakly lithified carbonate mud, while microsparite originates from recrystallization of micrite. Several crosscutting sets of calcite-filled microfractures. Sample 2009-D02. All images are oriented as sampled in the section. Scale bars $=2 \mathrm{~mm}$. 

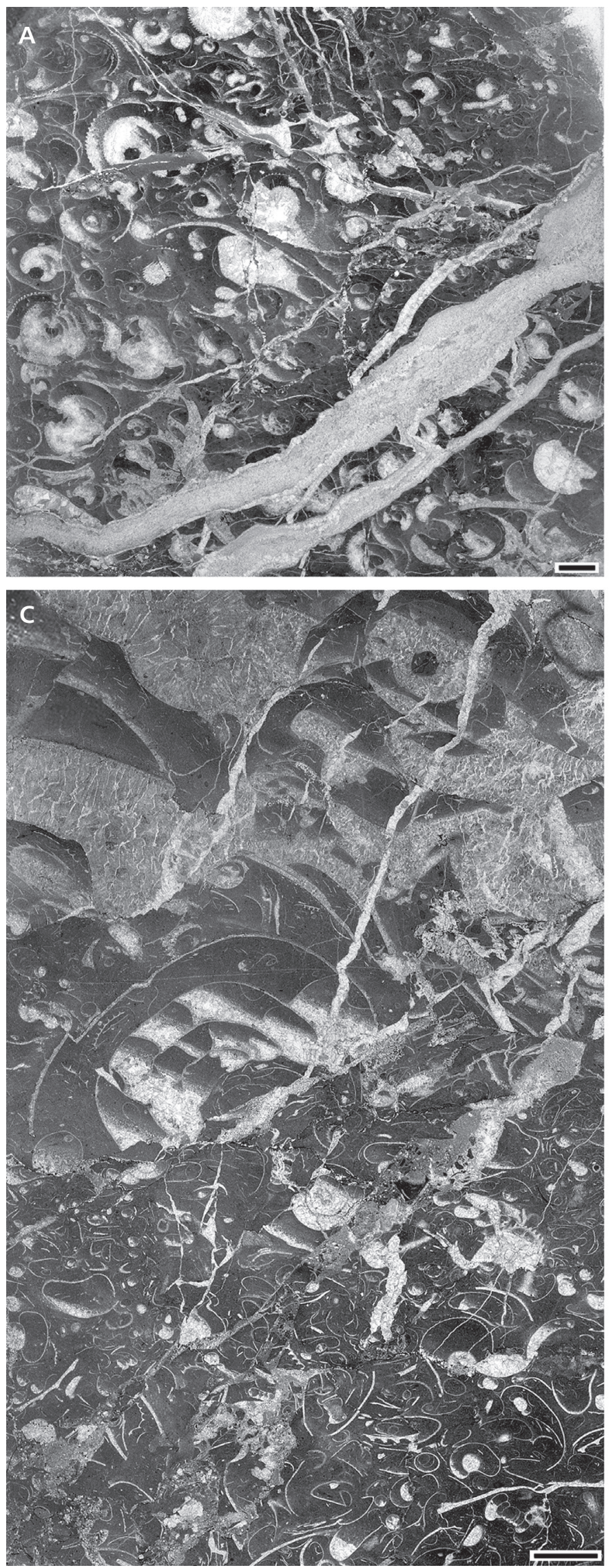
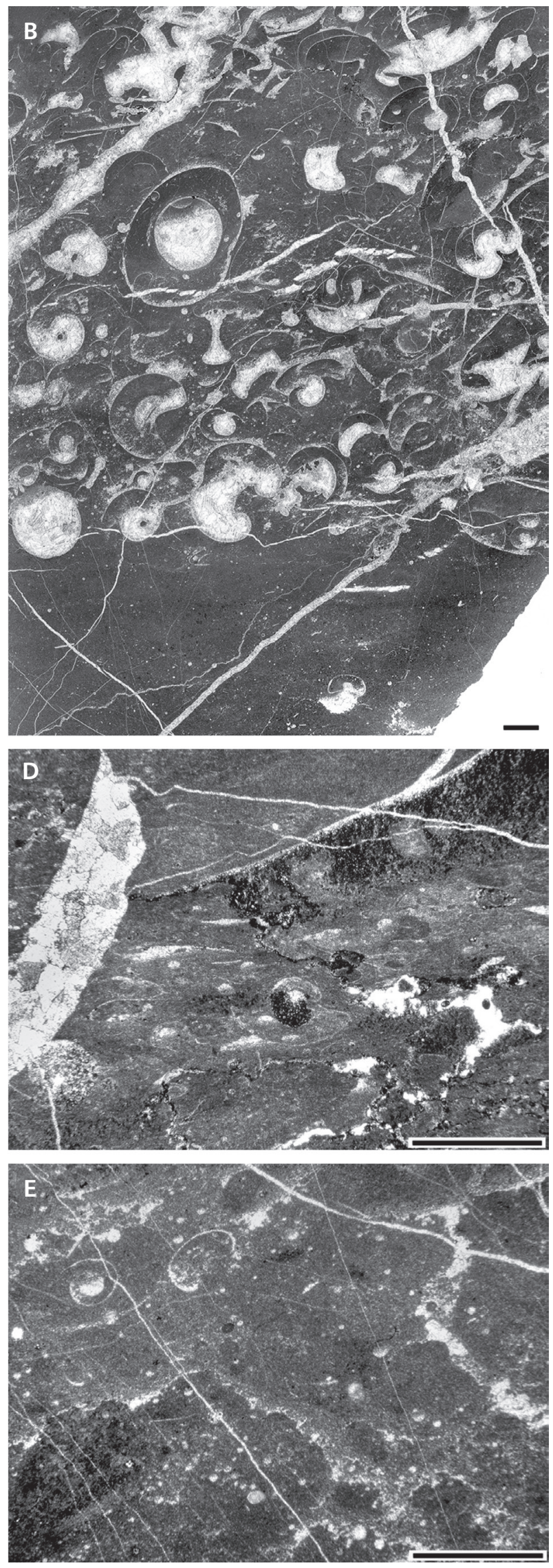
Irinoceras, Hypergoniatites, Cravenoceras, Lyrogoniatites, Pachylyroceras, Neoglyphioceras, Lusitanites, Ophilyroceras, Dombarocanites, Praedaraelites and Uralopronorites (Korn \& Sudar 2016). The correlation of the Viséan-Serpukhovian boundary in the Milivojevića Kamenjar section with time equivalent sections in other regions shows close resemblance to the Verkhnyaya Kardailovka section in the South Urals, but in that section, Dombarites occurs on both side of the boundary.

The recorded sedimentological features and microfacies types as well as pelagic fossil assemblages are characteristic of open-marine deep-shelf environments interrupted by occasional high-energy storm event deposition (tempestites). The sediment was subjected to deep burial diagenesis evidenced by strong compaction, pressure dissolution and nodular bedding fabric.

\section{Acknowledgements}

The research of Milan N. Sudar and Divna Jovanović was supported by the Ministry of Education, Science and Technological Development of the Republic of Serbia (Project ON-176015) and also by the Serbian Academy of Sciences and Arts (Project F-12). Matevž Novak was supported by the Slovenian Research Agency (ARRS; Program P1-0011 Regional Geology). Dieter Korn was supported by the German Research Foundation (DFG; project Ko1829/8-1). We thank Iwan Phillips (Berlin) for proofreading an earlier version of the manuscript and Carlo Corradini (Cagliari) and Tomáš Kumpan (Brno) for the thorough review of the manuscript.

\section{References}

Barskov, I.S., Alekseev, A.S., Kononova, L.I., \& Migdisova, A.V. 1987. Atlas of Upper Devonian and Carboiferous conodonts. 144 pp. Izdateljstvo Moskovskogo universiteta, Moskva. [in Russian]

Becker, R.T., Kaiser, S.I. \& Aretz, M. 2016. Review of chrono-, litho- and biostratigraphy across the global Hengenberg Crisis and Devonian-Carboniferous Boundary, 355-386. In BECKER, R.T., Königshof, P. \& Brett, C.E. (eds) Devonian Climate, See Level and Evolutionary Events, Geological Society London, Special Publication 423.

DOI 10.1144/SP423.10

BELKA, Z. 1985. Lower Carboniferous conodont biostratigraphy in the northeastern part of the Moravia-Silesia basin. Acta Geologica Polonica 35, 33-59.

Corradini, C. 2003. Late Devonian (Famennian) conodonts from the Corona Mizziu Sections near Villasalto (Sardinia, Italy). Palaeontographia Italica 89(2002), 65-116.

Corradini, C. 2008. Revision of Famennian-Tournaisian (Late Devonian-Early Carboniferous) conodont biostratigraphy of Sardinia, Italy. Revue de micropaléontologie 51(2008), 123-132. DOI 10.1016/j.revmic.2007.02.005

Corradini, C., Kaiser, S.I., Perri, M.C. \& Spalletta, C. 2011. Protognathodus (Conodonta) and its potential as a tool for defining the Devonian/Carboniferous Boundary. Rivista Italiana di Paleontologia e Stratigrafia 117(1), 15-28.

Corradini, C., Spalletta, C., Mossoni, A., Matyja, H. \& Over, D.J. 2016. Conodonts across the Devonian/Carboniferous boundary: a review and implication for the redefinition of the boundary and a proposal for an updated conodont zonation. Geological Magazine 154(4), 1-15.

DOI 10.1017/S0016756816000039X

Filipović, I. (ed.) 1995. The Carboniferous of Northwestern Serbia. Rasprave Geološkog zavoda "Gemini" 25, 1-104.

Filipović, I., Jovanović, D., Sudar, M., Pelikán, P., Kovács, S., Less, Gy. \& Hips, K. 2003. Comparison of the VariscanEarly Alpine evolution of the Jadar Block (NW Serbia) and "Bükkium" (NE Hungary) terranes; some paleogeographic implications. Slovak Geological Magazine 9(1), 23-40.

FlüGel, E. 2004. Microfacies of Carbonate Rocks. Analysis, Interpretation and Application. 976 pp. Springer, Berlin.

JI, Q. 1985. Study on the phylogeny, taxonomy, zonation and biofacies of Siphonodella (Conodonta). Bulletin of the Institute of Geology 11, 51-75.

Kaiser, S.I., Becker, R.T., Spalletta, C. \& Steuber, T. 2009. High-resolution conodont stratigraphy, biofacies and extinctions around the Hangenberg Event in pelagic successions from Austria, Italy and France. Palaeontographica Americana 63, 97-139.

Kalvoda, J., Kumpan, T. \& BÁBeK, O., 2015. Upper Famennian and Lower Tournaisian sections of the Moravian Karst (Moravo-Silesian Zone, Czech Republic): a proposed key area for correlation of the conodont and foraminiferal zonations. Geological Journal 50, 17-38. DOI 10.1002/gj.2523

Karamata, S. 2006. The geological development of the Balkan Peninsula related to the approach, collision and compression of Gondwanan and Eurasian units, 155-178. In ROBERTSON, A.H.F. \& Mountrakis, D. (eds) Tectonic development of the Eastern Mediterranean Region. Geological Society London, Special Publication 260.

Kolar-JurkovšEK, T. \& JuRKovšEK, B. 1994. Frasnian and ViseanNamurian conodont faunas at Praprotno, Slovenia. Rivista Italiana di Paleontologia e Stratigrafia 99(4), 427-440.

Korn, D. 1996. Revision of the Late Visean goniatite stratigraphy. Annales de la Société géologique de Belgique 117(1), 205-212.

Korn, D. 2006. Ammonoideen. Schriftenreihe der Deutschen Gesellschaft für Geowissenschaften 41, 147-170.

Korn, D. \& SudAr, M.N. 2010. The palaeogeographic position of the Jadar Block in the context of Early Carboniferous plate distribution, 165-166. In BANJAC N. (ed.) Zbornik radova 15. Kongres geologa Srbije sa međunarodnim učešćem, Beograd.

Korn, D. \& Sudar, M.N. 2016. The Late Devonian and Early 
Carboniferous ammonoids (Cephalopoda) from Milivojevića Kamenjar, Družetić (NW Serbia) and their stratigraphy. Bulletin of Geosciences 91(1), 187-220.

DOI 10.3140/bull.geosci.1578

Korn, D., Bockwinkel, J. \& Ebbighausen, V. 2007. Tournaisian and Viséan ammonoid stratigraphy in North Africa. Neues Jahrbuch für Geologie und Paläontologie, Abhandlungen 243(2), 127-148. DOI 10.1127/0077-7749/2007/0243-0127

Korn, D., Jovanović, D., Novak, M. \& Sudar, M.N. 2010a. Early late Viséan ammonoid faunas from the Jadar Block (NW Serbia). Geologica Carpathica 61(5), 355-364.

DOI 10.2478/v10096-010-0021-4

Korn, D., Sudar, M.N., Jovanović, D. \& Novak, M. 2010b. Study of Early Carboniferous at Milivojevića Kamenjar section in Družetić area (Jadar Block, NW Serbia). Newsletter on Carboniferous Stratigraphy 28, 67-68.

Korn, D., Sudar, M.N., Novak, M. \& Jovanović, D. 2010c. The palaeogeographic position of the Jadar Block (Vardar Zone, NW Serbia) in the Early Carboniferous. Scientific Annals, School of Geology, Aristotle University of Thessaloniki, Proceedings of the XIX Carpathian-Balkan Geological Association Congress, Thessaloniki, Greece, Special volume 100, 141-147.

Korn, D., Sudar, M.N., NovaK, M. \& Jovanović, D. 2010d. The palaeogeographic position of the Jadar Block (Vardar Zone, NW Serbia) in the Early Carboniferous. XIX Congress of the Carpathian-Balkan Geological Association, Thessaloniki, Greece, 23-26 September 2010, Abstract Volume, Geologica Balcanica 39(1-2), 203.

Korn, D., Titus, A.L., Ebbighausen, V., Mapes, R.H. \& Sudar, M.N. 2012. Early Carboniferous (Mississippian) ammonoid biogeography. Geobios 45(1), 67-77.

DOI 10.1016/j.geobios.2011.11.013

Lane, R.H., Sandberg, C.A. \& Ziegler, W. 1980. Taxonomy and phylogeny of some Lower Carboniferous conodonts and preliminary standard post-Siphonodella zonation. Geologica et Palaeontologica 14, 117-164.

Meischner, D. 1962. Rhenaer Kalk and Posidonienkalk im Kulm des nordöstlichen Rheinischen Schiefergebirges und der Kohlenkalk von Schreufa (Eder). Abhandlungen des Hessischen Landesamtes für Bodenforschung 39, 6-46.

Meischner, D. 1970. Conodonten-Chronologie des deutschen Karbons. Compte Rendue Sixième Congrès International de Stratigraphie et de Géologie du Carbonifère, Sheffield $11^{\text {th }}$ to $16^{\text {th }}$ September 1967 No. 3, 1169-1180.

Meischner, D. \& Nemyrovska, T.I. 1999. Origin of Gnathodus bilineatus (Roundy 1926) related to goniatite zonation in Rheinisches Schiefergebirge, Germany. Proceedings of the Seventh European Conodont Symposium. Bolletino della Societá Paleontologica Italiana 37(2-3) (for 1998), 427-442.

Mossoni, A., Carta, N., Corradini, C. \& Spalletta, C. 2015. Conodonts across the Devonian/Carboniferous boundary in SE Sardinia (Italy). Bulletin of Geosciences 90, 371-88.

DOI 10.3140/bull.geosci.1524
Nemyrovska, T.I. (with an appendix by SAmanKassou, E.) 2005. Late Viséan/early Serpukhovian conodont succession from the Triollo section, Palencia (Cantabrian Mountain, Spain). Scripta Geologica 129, 13-89.

Nemyrovska, T.I., Perret-Mirouse, M.-F. \& Weyant, M. 2006. The early Visean (Carboniferous) conodonts from the Saoura Valley. Acta Geologica Polonica 56, 361-370.

Nikolaeva, S.V. 2013a. New Viséan and Serpukhovian Ammonoids from the Verkhnyaya Kardailovka Section, Eastern Slope of the South Urals. Paleontologičeskij Žurnal 2013(4), 39-50.

Nikolaeva, S.V. 2013b. Ammonoids from the ViséanSerpukhovian boundary beds in the Verkhnyaya Kardailovka section. a progress report. Newsletter on Carboniferous Stratigraphy 30, 49-53.

Nikolaeva, S.V., Akhmetshina, L.Z., Konovalova, V.A., Korobkov, V.F. \& ZainakaEva, G.F. 2009a. The Carboniferous carbonates of the Dombar Hills (western Kazakhstan) and the problem of the Viséan-Serpukhovian boundary. Palaeoworld 18, 80-93. DOI 10.1016/j.palwor.2009.04.004

Nikolaeva, S.V., Alekseev, A.S., Kulagina, E.I., Gibshman, N.B., Richards, B.C., Gatovsky, Y.A. \& Konovalova, V.A. 2014. New microfacies and fossil records (ammonoids, conodonts, foraminifers) from the Visean-Serpukhovian boundary beds in the Verkhnyaya Kardailovka section. Newsletter on Carboniferous Stratigraphy 31, 41-51.

Nikolaeva, S.V., Gibshman, N.B., Kulagina, E.I., Barskov, L.S. \& Pazukhin, V.N. 2002. Correlation of the ViséanSerpukhovian boundary in its type region (Moscow Basin) and the South Urals and a proposal of boundary markers (ammonoids, foraminifers, conodonts). Newsletter on Carboniferous Stratigraphy 20, 16-21.

Nikolaeva, S.V., Kulagina, E.I., Pazukhin, V.N., Kochetova, N.N. \& Konovalova, V.A. 2009b. Paleontology and Microfacies of the Serpukhovian in the Verkhnyaya Kardailovka Section, South Urals, Russia. potential candidate for the GSSP for the Viséan-Serpukhovian boundary. Newsletter on Carboniferous Stratigraphy 43(2), 165-193.

DOI 10.1127/0078-0421/ 2009/0043-0165

Over, D.J. 1992. Conodonts and the Devonian-Carboniferous boundary in the upper Woodford Shale, Arbuckle Mountains, south-central Oklahoma. Journal of Paleontology 66(2), 293-311. DOI 10.1017/S0022336000033801

Pazukhin, V.N., Kulagina, E.I., Nikolaeva, S.V., Kochetova, N.N. \& Konovalova, V.A. 2010. The Serpukhovian Stage in the Verkhnyaya Kardailovka Section, South Urals. Stratigraphy and Geological Correlation 18, 269-289.

DOI 10.1134/S0869593810030044

QI, Y. \& WANG, Z. 2005. Serpukhovian conodont sequence and the Viséan-Serpukhovian boundary in South China. Rivista Italiana di Paleontologia e Stratigrafia 111(1), 3-10.

Qi, Y., Nemyrovska T.I., Wang, X., Chen, J., Wang, Z., Lane, H.R., Richards, B.C., Hu, K. \& WANG, Q. 2014. Late Visean-early Serpukhovian conodont succession at the Naqing (Nashui) 
section in Guizhou, South China. Geological Magazine 151(2), 254-268. DOI 10.1017/S001675681300071X

QI, Y., WANG, X., Wang, Z., LANE, H.R., Richards, B.C., Katsumi, U. \& Groves, J.R. 2009. Conodont biostratigraphy of the Naqing (Nashui) section in South China. candidate GSSPs for both the Serpukhovian and Moscovian Stages. Permophiles 53, $39-40$.

Ramovš, A. 1990a. Conodonten aus dem Unterkarbon von Jezersko, Zentral-Karawanken, Slowenien. Geologica et Palaeontologica 24, 89-107.

Ramovš, A. 1990b. Eine Conodonten fauna aus dem Unterkarbon südlich des Eisenbergwerkers Ljubija, West-Bosnien. Geologica et Palaeontologica 24, 109-113.

RAmovš, A. 1993. Spodnjekarbonski konodonti južno od Pavličevega sedla v Karavankah, Slovenija. Razprave IV. razreda SAZU 34(4), 105-115.

Ruzhencev, V.E. \& Bogoslovskaya, M.F. 1971. Namurian time in ammonoid evolution. Early Namurian ammonoids. Trudy Paleontologicheskogo Instituta Akademiya Nauk SSSR 133, 1-382. [in Russian]

Sandberg, C.A., Ziegler, W., Leuteritz, K. \& Brill, S.M. 1978. Phylogeny, speciation, and zonation of Siphonodella (Conodonta, Upper Devonian and Lower Carboniferous). Newsletters on Stratigraphy 7(2), 102-120.

DOI $10.1127 / \operatorname{nos} / 7 / 1978 / 102$

Scharfe, F. 1977. Conodontenfeinstratigraphische Untersuchungen im Oberdevon und Unterkarbon von Družetić in NW-Serbian (Vorbericht). Bulletin Académie Serbe des Sciences et des Arts, Classe des Sciences Techniques 15, 23-30.

Skompski, S., Alekseev, A., Meischner, D., Nemirovskaya, T., Perret, M.F. \& VArker, W.J. 1995. Conodont distribution across the Visean/Namurian boundary. Courier Forschungsinstitut Senckenberg 188, 177-209.

SomerviLle, I.D. 2008. Biostratigraphic zonation and correlation of Mississippian rocks in Western Europe. Some case studies in the late Viséan/Serpukhovian. Geological Journal 43, 209-240. DOI 10.1002/gj.1097

Spalletta, C., Perri, M.C., Over, D.J. \& Corradini, C. 2017. Famennian (Upper Devonian) conodont zonation: revised global standard. Bulletin of Geosciences 92(1), 31-57. DOI 10.3140/bull.geosci.1623
Spasov, H. \& Filipović, I. 1966. Konodontska fauna starijeg i mlađeg paleozoika JI i SZ Bosne. Geološki glasnik, Geološki zavod u Sarajevu 11, 33-53.

Spasov, H. \& Filipović, I. 1967. Devonian and Carboniferous conodont fauna from North-Western Serbia (Yugoslavia). Bulgarian Academy of Sciences, Bulletin of the Geological Institute, Serie Paleontology 16, 53-86. [in Bulgarian]

Spassov, C. 1976. Carboniferous conodont fauna from Western Serbia (Yugoslavia). Review of the Bulgarian Geological Society 37(2), 129-138. [in Bulgarian]

Stevanović, P. \& Kullmann, J. 1962. Namurian bei Družetić im westlichen Serbien und seine Goniatitenfauna. Bulletin Muséum d'Histoire Naturelle Belgrade (Glasnik Prirodnjačkog muzeja), A 1962(16, 17), 45-112.

WANG, Z. \& QI, Y. 2003. Report on the Upper ViséanSerpukhovian conodont zonation in South China. Newsletter on Carboniferous Stratigraphy 21, 22-24.

Wang, Q., Korn, D., Nemyrovska, T. \& QI, Y. 2018. The Wenne river bank section - an excellent section for the ViséanSerpukhovian boundary based on conodonts and ammonoids (Mississippian; Rhenish Mountains, Germany). Newsletters on Stratigraphy. DOI 10.1127/nos/2018/0440

Wang, Q., Qi, Y., Korn, D., Chen, J., Sheng, Q. \& Nemyrovska, T. 2017. Progress on the Viséan-Serpukhovian boundary in South China and Germany. Newsletter on Carboniferous Stratigraphy 33, 35-42.

Webster, G.D. \& Groessens, E. 1990. Conodont subdivision of the Lower Carboniferous. Courier Forschungsinstitut Senckenberg 130, 31-40.

Ziegler, W. 1971. Conodont Stratigraphy of the European Devonian, 227-284. In Sweet, W.C. \& Bergstrom, S.M. (eds) Symposium on Conodont Stratigraphy, Geological Society of America Memoir 127.

Ziegler, W. \& SANDBerg, C.A. 1984. Palmatolepis-based revision of upper part of standard Late Devonian conodont zonation, 179-194. In Clark, D.L. (ed.) Conodont Biofacies and Provincialism. Geological Society of America, Special Paper 196.

Ziegler, W., Sandberg, C.A. \& Austin, R.L. 1974. Revision of Bispathodus group (Conodonta) in the Upper Devonian and Lower Carboniferous. Geologica et Palaeontologica 8, 97-112. 
Appendix. List of co-occurrences of conodont species (only platform elements) in the samples from Milivojevića Kamenjar.

\begin{tabular}{|c|c|c|c|c|c|c|c|c|c|c|c|c|c|c|c|c|c|c|c|c|c|c|c|c|c|c|c|c|}
\hline Sample & 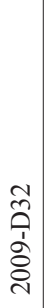 & 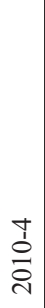 & 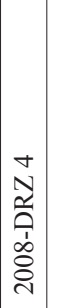 & 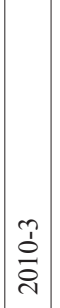 & 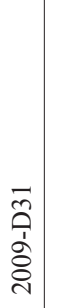 & 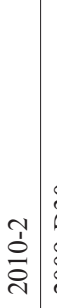 & 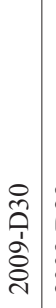 & 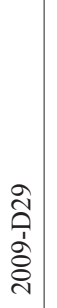 & 홍 & 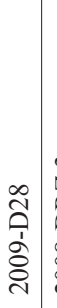 & 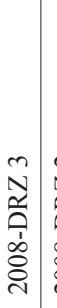 & 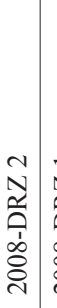 & 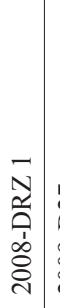 & 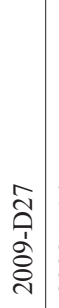 & 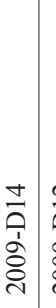 & 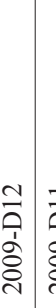 & 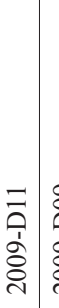 & 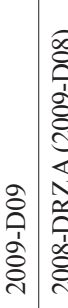 & 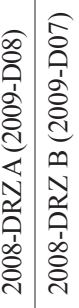 & 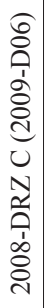 & 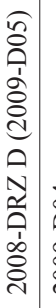 & 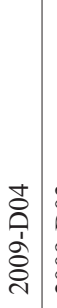 & 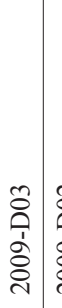 & 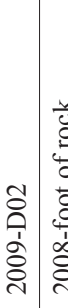 & 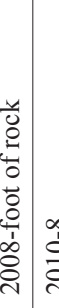 & 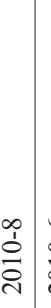 & 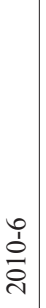 & 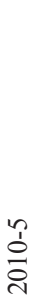 \\
\hline Pa. gracilis expansa & & & 1 & & & & 1 & & & & & & & & & & & & & & & & & & & & & \\
\hline Pa. gracilis gracilis & 2 & 2 & 5 & 4 & 5 & 5 & 8 & & & & & & & & & & & & & & & & & & & & & \\
\hline Pa. gracilis sigmoidalis & 2 & 1 & 2 & 1 & 3 & 2 & 4 & & & & & & & & & & & & & & & & & & & & & \\
\hline Bi. aculeatus & 2 & 1 & & & 1 & 1 & 2 & 2 & & & & & & & & & & & & & & & & & & & & \\
\hline Bi. costatus & 2 & 1 & 1 & 1 & 1 & 1 & 1 & & & & & & & & & & & & & & & & & & & & & \\
\hline Bi. bispathodus & & 1 & & & & & & & & & & & & & & & & & & & & & & & & & & \\
\hline Bi. spinulicostatus & & & & & 1 & & & 1 & & & & & & & & & & & & & & & & & & & & \\
\hline Bi. stabilis & & 2 & 1 & 1 & 1 & 1 & 2 & 2 & 2 & 5 & 4 & & & & & & & & & & & & & & & & & \\
\hline Bi. ultimus & 1 & 1 & 2 & 2 & 1 & 1 & 2 & 1 & & & & & & & & & & & & & & & & & & & & \\
\hline Po. inornatus & 1 & 1 & & & & & & & & 1 & 2 & & & & & & & & & & & & & & & & & \\
\hline Po. comminis communis & & 6 & 8 & 3 & 2 & & 1 & 1 & 6 & 2 & 6 & & & & & & & & & & & & & & & & & \\
\hline Po. communis collinsoni & & & & & & & & & 1 & & & & & & & & & & & & & & & & & & & \\
\hline Po. communis carina & & & & & & & & & & 2 & & & & & & & & & & & & & & & & & & \\
\hline Po. purus purus & & & & & & & & & 3 & 2 & 8 & & & & & & & & & & & & & & & & & \\
\hline Po. purus subplanus & & & & & & & & 3 & 2 & & & & & & & & & & & & & & & & & & & \\
\hline Po. vogesi & & & & & & & & 1 & & & & & & & & & & & & & & & & & & & & \\
\hline Po. longiposticus & & & & & & & & & & 1 & & & & & & & & & & & & & & & & & & \\
\hline Po. bischoffi & & & & & & & & & & & 3 & & & & & & & & & & & & & & & & & \\
\hline Si. praesulcata & 2 & & 5 & 1 & 2 & & 6 & 1 & & & & & & & & & & & & & & & & & & & & \\
\hline Si. sulcata & & & & & & & & 5 & 2 & 2 & & & & & & & & & & & & & & & & & & \\
\hline Si. duplicata & & & & & & & & & & 5 & & & & & & & & & & & & & & & & & & \\
\hline Si. carinthiaca & & & & & & & & & & 1 & & & & & & & & & & & & & & & & & & \\
\hline Ps. marburgensis trigonicus & & & 1 & & & & 1 & & & & & & & & & & & & & & & & & & & & & \\
\hline Ps. marginatus & & & & & & & & & & & 2 & & & & & & & & & & & & & & & & & \\
\hline Ps. pinnatus & & & & & & & & & & & 2 & & & & & & & & & & & & & & & & & \\
\hline Ps. primus & & & & & & & & & 10 & 2 & & & & & & & & & & & & & & & & & & \\
\hline Ps. triangulus & & & & & & & & & & & 2 & & & & & & & & & & & & & & & & & \\
\hline Pg. homopunctatus & & & & & & & & & & & 2 & & & & & & & & & & & & & & & & & \\
\hline Gn. pseudosemiglaber & & & & & & & & & & & 6 & 8 & 2 & & & & & & & & & & & & & & & \\
\hline Gn. semiglaber & & & & & & & & & & & \begin{tabular}{l|l}
2 & 1 \\
\end{tabular} & 10 & 5 & & & & & & & & & & & & & & & \\
\hline Gn. punctatus & & & & & & & & & & & 1 & & & & & & & & & & & & & & & & & \\
\hline Gn. austini & & & & & & & & & & & & 3 & 1 & & & & & & & & & & & & & & & \\
\hline Gn. girtyi & & & & & & & & & & & & & & & & & 1 & & & & 1 & & & & & & & \\
\hline Gn. praebilineatus & & & & & & & & & & & & \begin{tabular}{l|l}
10 & 1 \\
\end{tabular} & 10 & 1 & & & & & & & & & & & & & & \\
\hline Gn. bilineatus bilineatus & & & & & & & & & & & & \begin{tabular}{l|l}
2 & 2 \\
\end{tabular} & 20 & 1 & 2 & \begin{tabular}{l|l}
2 & 2 \\
\end{tabular} & \begin{tabular}{l|l}
2 & 1 \\
\end{tabular} & \begin{tabular}{l|l}
1 & 10 \\
\end{tabular} & \begin{tabular}{|l|l|}
10 & 2 \\
\end{tabular} & 8 & 4 & 4 & \begin{tabular}{l|l}
1 & 5 \\
\end{tabular} & \begin{tabular}{l|l}
5 & 6 \\
\end{tabular} & \begin{tabular}{l|l}
6 & 20 \\
\end{tabular} & 20 & & 8 \\
\hline Gn. bilineatus remus & & & & & & & & & & & & & 5 & & & & & & & & & & & & & & & \\
\hline Gn. bilineatus romulus & & & & & & & & & & & & & 5 & & & & & & & & & & & & & & & \\
\hline Gn. bilineatus bollandensis & & & & & & & & & & & & & & & & & & & & & & & & & & & 2 & 5 \\
\hline Gn. delicatus & & & & & & & & & & & 2 & 2 & 2 & & & & & & & & & & & & & & & \\
\hline Lo. commutata & & & & & & & & & & & \begin{tabular}{l|l}
4 & 1 \\
\end{tabular} & \begin{tabular}{l|l}
15 & 1 \\
\end{tabular} & 10 & 1 & 1 & & \begin{tabular}{l|l}
2 & 1 \\
\end{tabular} & \begin{tabular}{l|l}
1 & 5 \\
\end{tabular} & 5 & & & & & & & 10 & 1 & 5 \\
\hline Lo. scotiensis & & & & & & & & & & & & & & & & & & & 1 & & & & & & & & & \\
\hline Lo. mononodosa & & & & & & & & & & & & & & & & & & & \begin{tabular}{|l|l|}
8 & 2 \\
\end{tabular} & 2 & & & & & & 8 & & 2 \\
\hline Lo. multinodosa & & & & & & & & & & & & & & & & & & & \begin{tabular}{|l|l|}
3 & 1 \\
\end{tabular} & 5 & & & & & \begin{tabular}{l|l}
4 & 4 \\
\end{tabular} & 4 & & 2 \\
\hline Lo. nodosa & & & & & & & & & & & & & & & & & \begin{tabular}{l|l}
5 & 1 \\
\end{tabular} & \begin{tabular}{l|l}
1 & 10 \\
\end{tabular} & \begin{tabular}{|l|l|}
0 & 5 \\
\end{tabular} & 4 & & & & & \begin{tabular}{l|l}
5 & 8 \\
\end{tabular} & 8 & & 5 \\
\hline Lo. senckenbergica & & & & & & & & & & & & & & & & & & & \begin{tabular}{|l|l|}
6 & 3 \\
\end{tabular} & & & & & & & 10 & & 6 \\
\hline Lo. ziegleri & & & & & & & & & & & & & & & & & & & \begin{tabular}{|l|l|}
5 & 5 \\
\end{tabular} & 6 & & & & & \begin{tabular}{|l|l|}
5 & 20 \\
\end{tabular} & 20 & 1 & 10 \\
\hline
\end{tabular}

